\title{
VOORGESCHIEDENIS, OPZET EN RESULTATEN VAN HET SURINAAMSE TIENJARENPLAN
}

\author{
INLEIDING
}

Ofschoon de financiële toestand van het land na r95o aanzienlijk verbeterde, dank zij de vermeerderde belastinginkomsten uit de enorm gestegen produktie der twee bauxietmaatschappijen, was het Suriname nochtans niet gegeven tot een sluitende begroting te komen, evenmin als zulks in de voorafgaande jaren mogelijk was.

De noodzaak om de geaccumuleerde sociale en economische achterstand van jaren spoedig in te halen, hetgeen zonder een krachtige versterking van het Overheidsapparaat onmogelijk bleek, was zo urgent, dat dit, met de sterk gestegen lonen en materiaalprijzen oorzaak was van de onvoldoende financieringsmogelijkheid van de begroting, inzonderheid van de kapitaaldienst.

Zonder financiële hulp van het buitenland zou niet alleen de situatie steeds ongunstiger worden, maar moest het land jaar op jaar aangewezen blijven op een bijdrage uit de Nederlandse schatkist om het begrotingstekort te dekken.

In Nederland werd dan ook begrepen, dat, wilde inhoud worden gegeven aan het na de tweede wereldoorlog met overtuiging nagestreefde verantwoordelijke zelfbestuur voor de Overzeese Rijksdelen, Suriname allereerst financiële onafhankelijkheid moest verwerven.

Het land diende daarom in staat te worden gesteld, om de sociaaleconomische structuur zodanig te wijzigen, dat in de komende jaren op eigen kracht een gestadige en evenwichtige stijging van het reëel nationaal inkomen per hoofd kon worden gerealiseerd en het chronische tekort op de betalingsbalans, inzonderheid met Nederland, blijvend kon worden opgeheven.

Grote investeringen waren daarvoor nodig, welke voornamelijk van de overheid zouden moeten komen, aangezien van private 
zijde niet alleen geen belangstelling bestond voor de financiering van maatregelen ter verbetering van de infrastructuur, maar helaas evenmin voor winstbeogende projekten, welke bij welslagen voor de nationale economie van grote betekenis plegen te zijn.

Het binnenlandse kapitaal was daarvoor te gering en te zeer geïnteresseerd in weinig risico dragende beleggingen in onroerende goederen en hypotheken. Buitenlandse beleggers met uitzondering van de bauxietmaatschappijen, zagen onder invloed van de teleurstellende resultaten van vroegere investeringen, de minder gunstige aspecten van het Surinaamse investeringsklimaat sterk vergroot.

In verband met dit alles besloot Nederland in 1947 tot de oprichting van een Welvaartsfonds voor Suriname, waaraan een kapitaal van Nf. 40 mln ter beschikking werd gesteld.

Met dit bedrag dienden in de eerste plaats fundamentele onderzoekingen op verschillend gebied te worden ingesteld, waarvan de resultaten mettertijd een basis konden vormen voor een veeljarig plan, dat een evenwichtige ontplooiing beoogde van de kleine, maar gecompliceerde Surinaamse maatschappij, binnen het kader der financiële, technische en economische mogelijkheden.

Allereerst werd de luchtkartering van het land benoorden de 4de breedtegraad ter hand genomen met de daarop aansluitende foto-interpretatie en cartografie, omdat betrouwbare topografische kaarten voor terreinwerkers op agrarisch en geologischmijnbouwkundig gebied volstrekt onmisbaar waren.

Ook werd een tweede volkstelling georganiseerd omdat men in het duister tastte hoe de bevolking zich sinds 1920 in omvang en samenstelling had ontwikkeld.

Verder vertrok uit Nederland een commissie met de opdracht, de expansiemogelijkheden van de Surinaamse landbouw te bestuderen. Op grond van deze studie werd omstreeks $195^{\circ}$ in het Westelijk deel van de kuststrook een proefpolder van 250 ha ingericht, waar onder leiding van het Departement van Landbouw, Veeteelt en Visserij de problemen van een gemechaniseerde landbouw tot oplossing zouden worden gebracht. Daarna kon een aanvang worden gemaakt met de uitvoering van een 50.000 ha groot projekt voor de vestiging van Nederlandse boeren op grote gemotoriseerde gezinsbedrijven, welke voornamelijk sawah-rijst maar ook soya voor export produceerden. Met de nadere uitwerking en uitvoering van dit emigratieplan, het latere "Wa- 
geningen projekt" werd een, door de Nederlandse en Surinaamse regeringen gezamenlijk opgerichte 'Stichting voor de ontwikkeling van machinale landbouw in Suriname' (S.M.L.), belast.

Deze organisatie ontving verder de opdracht de vooruitzichten te onderzoeken van middelgrote landbouwbedrijven op een niet ver van Paramaribo gelegen oude plantage, welke deel uitmaakte van een achter de kuststrook voorkomend groot areaal, nog voornamelijk braak liggende 'droge' gronden, het latere Lelydorpplan.(I)

Men meende, dat het in cultuur brengen van gronden hier een geringere kapitaalsinvestering zou vereisen dan in de kuststrook, aangezien het kostbare inpolderingswerk achterwege kon blijven, een veronderstelling welke later vaak onjuist bleek te zijn.

In samenhang met dit projekt werd een voedselbalans opgesteld in de hoop, op grond daarvan richtlijnen te kunnen aangeven hoe de klein-landbouw zich in de komende jaren zou moeten ontwikkelen om de bevolking, in het bijzonder van de hoofdstad, een volwaardig dieet te verschaffen met een zo gering mogelijke import van voedingsmiddelen, niet alleen ter besparing van deviezen, welke Suriname in de allereerste fase van zijn ontwikkeling zo hard nodig had, maar ook om door eigen produktie van agrarische consumptiegoederen de kosten van levensonderhoud te drukken.

Ook kreeg de S.M.L. de leiding van een door het Welvaartsfonds aangekochte, in de kuststrook gelegen verlaten koffieplantage, waar enerzijds zou worden onderzocht of door motorisatie aan het tekort aan plantage-arbeiders kon worden tegemoetgekomen, anderzijds of herwinning van deze, slechts met secundair bos en de overblijfselen van de cultuuraanplantingen bedekte complexen, met minder kosten gepaard zou gaan dan aanwinning van nieuw land, het z.g. Slootwijkplan.

In de veronderstelling, dat in de naaste toekomst de industriële ontplooiing van Suriname een goedkope krachtbron zou behoeven en Suriname vermoedelijk niet over steenkolen, aardgas of olie beschikte, deed het Welvaartsfonds onderzoeken, in hoeverre het opwekken van hydroëlectrische energie in de Suriname-rivier te realiseren was, uit welke studie later het bekende Brokopondoplan voortkwam.

Ogenschijnlijk streefde het Welvaartsfonds echter ook naar een directe verbetering van de sociaal-economische toestand door aanleg van nieuwe en sanering van bestaande landbouwarealen, verbetering van het verkeer te land en te water, be- 
vordering van de volksgezondheid, volkswoningbouw en handel, credietverlening aan de kleine man, etc. (2). In feite waren dit echter evenzo experimenten om een inzicht te verkrijgen hoe deze activiteiten zich in de komende jaren verder zouden moeten ontwikkelen om de grootste netto bijdrage te leveren in het nationaal produkt.

Uit deze gezichtshoek bezien heeft het Welvaartsfonds tijdens zijn vijfjarig bestaan zeer verdienstelijk werk verricht, niettegenstaande verschillende experimenten door onvoldoende voorbereiding en te grootse aanpak, in verhouding tot het verkregen nut, te kostbaar zijn geweest.

Het bedrag van Nf. 40 mln dat na de devaluatie van de Nederlandse gulden voor Suriname nog slechts een waarde vertegenwoordigde van Sf. 20 mln, was in I95I voor een aanzienlijk deel verwerkt of gecommitteerd.

De Nederlandse Regering, dit voorziende, had reeds dadelijk erop aangedrongen, om de opstelling van een algemeen ontwikkelings- en financieringsplan waarin verschillende elementen van de economische opbouw van Suriname een harmonisch geheel zouden vormen, in het werkprogramma van het Welvaartsfonds op te nemen, omdat zij slechts aan de hand van een dergelijk plan tot verdere financiering bereid was.

Maar ook de Surinaamse Regering was tot het inzicht gekomen, dat de richtlijnen voor haar beleid op lange termijn in een plan moesten worden vastgelegd, wilde de toeneming van het nationale inkomen niet bij het bevolkingsaccres achterblijven. Daarom riep zij medio I95I een Planbureau in het leven als waarborg dat de te ontwerpen deelplannen in de verschillende onderling van elkaar afhankelijke sektoren van de volkshuishouding, naar aard, tijdstip en tempo gecoördineerd zouden worden ontworpen en uitgevoerd, binnen het raam der daarvoor uitgetrokken gelden en van de beschikbare werkkrachten, in het bijzonder der geschoolde arbeiders. Bovendien kon dit bureau ervoor zorgdragen, dat de inhoud van het plan periodiek werd aangepast aan de uitkomsten van het voortgezette wetenschappelijk onderzoek en aan de wijzigingen welke zich in de loop der jaren in de sociaal-economische en financieel-monetaire toestand van het land zouden voordoen.

Hoewel het Planbureau de stichtingsvorm kreeg als waarborg, dat het beleid zoveel mogelijk zou worden bepaald door zakelijke en niet door politieke overwegingen, werd het toch onder de bevelen gesteld van de 
Minister-President, omdat slechts dan een vlotte en een volgens de planrichtlijnen verlopende medewerking van alle departementen verzekerd was. De evenwichtige opzet van het plan zou nimmer door een te grote of te geringe activiteit van een der departementen in gevaar mogen worden gebracht.

Later toen het Planbureau zijn begroting zag geïncorporeerd in de buitengewone dienst van het land, verloor het echter ook zijn financiële zelfstandigheid. De overheid meende namelijk te moeten voorkomen, dat het planorgaan, evenals vroeger het Welvaartsfonds, te diep zou ingrijpen in het werk van de diensten die met de eigenlijke uitvoering der projekten zouden worden belast, waardoor hun zelfwerkzaamheid instede van gestimuleerd, zou worden verlamd. Ook wenste men niet, dat het Planbureau een staat in de staat zou vormen, waardoor de verantwoordelijkheid voor's Lands ontwikkeling niet meer ten volle bij de Regering zou berusten.

Het Planbureau ontving de opdracht om in nauwe samenwerking met de departementen, een tienjarig plan te ontwerpen, waarvan de kosten een bedrag van Sf. Ioo mln niet te boven mochten gaan.

Nederland kon in verband met zijn omstreeks $195^{\circ}$ nog zwakke financiële positie, voor het plan slechts Sf. $20 \mathrm{mln}$ in de vorm van langlopende leningen ter beschikking stellen waarbij echter in aanmerking diende te worden genomen, dat het Suriname een zwaar drukkende oude lening van Sf. II mln kwijt schold en zich verder garant stelde voor een door de S.M.L. op vrije Nederlandse kapitaalmarkt op te nemen lening van Sf. $20 \mathrm{mln}$ alsmede voor een eventueel door Suriname bij de International Bank for Development and Reconstruction te sluiten dollarlening eveneens ter waarde van Sf. $20 \mathrm{mln}$.

Suriname zou, indien grote soberheid werd betracht, in de komende tien jaar uit eigen middelen voor dit doel hooguit Sf. $40 \mathrm{mln}$ kunnen besparen omdat naast het nakomen van de verplichtingen welke uit de leningen voortvloeiden, rekening gehouden moest worden met de additionele kosten voor exploitatie en onderhoud van de tijdens de planperiode gereed komende projekten.

Het was duidelijk dat met een bedrag van Sf. roo mln hoogstens een minimumplan kon worden opgesteld, waarin slechts plaats zou zijn voor projekten, welke een grote en snelle bijdrage zouden leveren tot het bereiken der doelstellingen.

De minder urgent geachte deelplannen, welke niettemin een waardevolle versterking van de sociaal-economische structuur van het land betekenden, zouden tot een bedrag van Sf. $30 \mathrm{mln}$ in een supplementair plan kunnen worden opgenomen, hetwelk 
later, indien de financieel-monetaire situatie zich gunstig ontwikkelde, eveneens tot uitvoering kon komen. De opdracht hield verder in, dat de door het Welvaartsfonds aangevangen werken en onderzoekingen moesten worden voortgezet, een eis, welke niet altijd aan inhoud en opzet van het plan ten goede is gekomen.

Leek de opdracht van het Planbureau niet te moeilijk uitvoerbaar, reeds een oppervlakkige analyse bracht aan het licht, dat het land en zijn samenleving enige niet, althans zeer moeilijk te wijzigen aspecten vertoonden, welke een beletsel vormden voor de economische ontwikkeling terwijl het gemis aan statistische basisgegevens op vrijwel ieder gebied de taak van het Planbureau nog in aanzienlijke mate verzwaarde.

Eveneens was het een hachelijke zaak een verantwoorde keuze te doen uit de projekten welke voor een direkte uitvoering in aanmerking kwamen, aangezien zij behoorden te worden gekozen uit enige alternatieven op grond van een zorgvuldig tegen elkaar afwegen der economische en sociale mérites. In het bijzonder was dit het geval wanneer het projekten betrof ter verhoging van de produktiviteit van de landbouw, omdat zij alle nog zeer veel onderzoek behoefden op demografisch, landbouwkundig, civiel-technisch en markt-analytisch terrein, alsmede op het gebied der grondrechten.

Bovendien was het welslagen van projekten ter bevordering van de klein-landbouw van vele omstandigheden afhankelijk, niet het minst van de medewerking welke de boerenbevolking op vrijwillige basis daaraan wenste te geven, een factor die zonder voorafgaande langdurige economische en sociologische verkenning, moeilijk te peilen was.

Van de factoren welke de vooruitgang remden waren de geringe omvang, de heterogene samenstelling en de ongunstige verdeling van de bevolking over de stad en platteland, wellicht het belangrijkst.

Omstreeks I950 bedroeg de getelde bevolking van Suriname, dus exclusief circa 21.000 diep in het binnenland gevestigde Boslandbewoners rond 177.000 zielen, waarvan respectievelijk $4 \mathrm{I}, 35,20$ en $4 \%$ behoorde tot de groep der Creolen, Voor-Indiërs, Indonesiërs en andere landaarden.

Van de totale bevolking was $40 \%$ in de hoofdstad woonachtig en $60 \%$ op het platteland. Van de plattelandsbevolking leefde echter $71 \%$ binnen een straal van $40 \mathrm{~km}$ rond de hoofdstad. Ruim $86 \%$ van de totale bevolking was dus in en om Paramaribo samengeperst op een areaal van circa $2500 \mathrm{~km}^{2}$ of $\mathrm{I}, 8 \%$ van het geografisch oppervlak van het land.

Deze situatie stond buiten elke verhouding tot de bestaansmogelijk- 
heden in dit gebied, wat in het relatief groot aantal werklozen in de stad tot uiting kwam. De bijdrage van destadsbevolking in het nationaal inkomen bedroeg dan ook slechts $20 \%$,(3) niettegenstaande het merendeel der industriële en ambachtelijke bedrijven met uitzondering van de houtzagerijen en rijstpellerijen, in en rond Paramaribo was gevestigd.

Ongeveer $71 \%$ van de stadsbevolking bestond uit Creolen, $18 \%$ uit Hindostanen, $5 \%$ uit Javanen, de rest behoorde tot andere landaarden. Van de plattelandsbevolking bestond slechts $20 \%$ uit Creolen, waaruit volgt, dat de bewoners van de stad overwegend Creolen, die van het platteland overwegend Aziaten waren.

Behalve circa 3700 Indianen, de oerbewoners van het land, bestond de ganse bevolking uit de nakomelingen van de eertijds voornamelijk uit West-Afrika en Azië ten behoeve van de plantages aangevoerde werkkrachten.

Hoewel allen onder een staatsgezag leefden en in het primitieve neger-engels een soort gemeenschappelijke voertaal hadden, vormde de Surinaamse samenleving allerminst een eenheid, omdat de rasgroepen te veel vast hielden aan de eigen taal, godsdienst, zeden en gebruiken (4). Voor het welslagen van een nationaal plan school in de tendenz om de belangen van de groep te laten prevaleren boven die van het land een ernstig gevaar, dat te reëler werd toen bleek, dat de politieke partijen zich langs raciale lijnen ontwikkelden.

Slechts een zeer krachtige, stabiele Regering, bereid om in 's Lands belang ook minder populaire maatregelen te treffen, zou in deze omstandigheden voor een goede gang van zaken kunnen borg staan.

Ook de volksopvoeding door onderwijs en voorlichting, die juist in de plurale Surinaamse maatschappij, een uiterst belangrijke rol had te spelen, zag zich door de heterogene samenstelling van de bevolking voor grote problemen geplaatst omdat van oudsher het Nederlands als voertaal werd gebezigd, terwijl de kinderen gewoon waren thuis Neger-engels, Hindi-dialecten of Javaans te spreken. De invloed van het onderwijs op het denken en doen van de jeugd werd daardoor verzwakt.

De geringe omvang, van de bovendien in brede lagen weinig koopkrachtige bevolking, waarvan slechts $10,4 \%$ een netto jaarinkomen had van meer dan Sf. Iooo terwijl van deze inkomens niet minder dan $65 \%$ tussen Sf. Iooo en Sf. 2000 lag, impliceerde een zeer beperkt binnenlands afzetgebied.

Deze omstandigheden verhinderen veelal aan industriële bedrijven die zich wilden toeleggen op de voortbrenging van verbruiksgoederen, de minimum omvang te geven, welke voor een lonende produktie werd vereist. Behoudens in enkele uitzonder- 
lijke gevallen kon de oplossing van dit probleem niet worden gezocht in protectionisme dat in dit stadium slechts economisch onverantwoorde bedrijven in het leven zou roepen.

Helaas was het voor industriële bedrijven moeilijk de rentabiliteitsgrens te bereiken door de produktie mede op buitenlandse markten te richten, daar de omliggende landen die een natuurlijk afzetgebied hadden kunnen vormen, evenzo sterk agrarisch waren georiënteerd en dichtbevolkt als zij waren, in de bevordering en bescherming van de industrie eveneens soulaas zochten voor de toenemende bevolkingsdruk in de landbouwsektor. Bovendien werd de intercaraïbische handel zeer bemoeilijkt door de slechte scheepvaartverbindingen en hoge vrachttarieven.

Maar ook al ware dit alles anders geweest, dan zou Suriname op deze markten toch niet hebben kunnen concurreren tegen de geïndustrialiseerde landen van N. Amerika en Europa, die met hun massaproduktie en export steunende maatregelen, vrijwel elke mededinging onmogelijk maakten. Slechts voor enkele speciale industriële produkten zou Suriname in het Caraïbisch gebied en in de geïndustrialiseerde landen mogelijk een afzet kunnen vinden.

Een andere factor die de export bemoeilijkte was het feit, dat Suriname in 1949 niet met de Nederlandse gulden en het Pond Sterling devalueerde. De landsinkomsten uit de bauxietproduktie zouden daardoor sterk zijn verminderd omdat de waarde van de voor $80 \%$ op de U.S.A. gerichte bauxietexport nl. contractueel in Surinaamse guldens was vastgesteld. Devaluatie zou ook hebben geleid tot een verhoging van de kosten van levensonderhoud en dientengevolge van het loonpeil, aangezien toentertijd circa $40 \%$ van de import uit de U.S.A. afkomstig was en bijna de helft der uitbetaalde lonen aan ingevoerde verbruiksgoederen werd besteed.

In vergelijking met de omliggende landen was het loonpeil in Suriname reeds hoog en mede oorzaak van de geringe concurrentiekracht der Surinaamse produkten. Dit hoge loonniveau was nochtans reëel, daar de prijs der geïmporteerde verbruiksgoederen, die in $195176 \%$ van de totale invoerwaarde vertegenwoordigden, in vergelijking met de landen van herkomst hoog was, wat in de eerste plaats verband hield met de zware vervoerskosten. In I95I bedroeg de invoerwaarde van goederen uit N. Amerika 40,8\% van het totaal, van die uit Europa 42,8\% (Nederland 28,4\%), gebieden die ruwweg respectievelijk 5000 en $7000 \mathrm{~km}$ van Paramaribo zijn gelegen. Andere oorzaken 
waren de zware invoerrechten, welke een zeer voorname bron van inkomsten voor het land vormden en de hoge handelsmarges, een gevolg van de minder doeltreffende organisatie van de import en distribuerende handel, en van de geringe omzet per artikel, welke door raciale voorkeuren nog verder werd verbrokkeld.

Doch ook de prijzen der lokaal voortgebrachte voedingsmiddelen die de stadsbevolking had te betalen waren hoog door de winstneming van de tussenhandel, de hoge transportkosten als gevolg van het onvoldoende ontwikkelde verkeersnet en van monopolistische praktijken der marktkooplieden.

Weliswaar verlichtte de Overheid de levenskosten van de stadsbevolking door de rijst, het voornaamste voedsel, aan een maximumprijs te binden, maar deze maatregel had een nadelige invloed op het toch reeds zo lage inkomen van de producenten waar echter tegenover stond, dat de rijstverbouwers op een zeker basis-inkomen konden rekenen, aangezien ook een minimumprijs werd vastgesteld.

Dat het loonpeil, niettegenstaande het grote aantal 'zichtbare' geheel en gedeeltelijk werklozen, niet daalde, hield enerzijds verband met de immobiliteit van de arbeid, anderzijds met een op Westerse leest geschoeide steunregeling. Het geregistreerde aantal werklozen en semi-werklozen in Paramaribo werd in I950 op circa 4000 geschat, een cijfer, dat echter geflatteerd was, omdat niet alle werkzoekenden zich lieten inschrijven, evenmin als zij die parasiteerden op de hoge inkomsten van de arbeiders in de sterk gemechaniseerde bauxietindustrie, die in de hoofdstad hun domicilie hadden.

Wat de betrekkelijke immobiliteit van de arbeid tussen de beroepen betrof, bleken Creolen en Hindostanen niet meer genegen te zijn tot arbeid op de plantages, niettegenstaande goede lonen en behoorlijke sociale voorzieningen. Slechts de Javaan was daartoe nog bereid, soms als vaste werkkracht, meestal echter als los arbeider, in de perioden dat de werkzaamheden op het eigen, overigens zeer kleine landbouwbedrijf, dit toelieten.

De Creool voelde zich het meest aangetrokken tot arbeid in de gemechaniseerde mijnbouw, industriële en transportbedrijven, het ambacht en intellectuele beroepen. De landbouw werd door hem slechts beoefend indien het de teelt van zeer arbeidsextensieve handelsgewassen betrof, zoals de klappercultuur, die daarom juist in het Creolendistrict Coronie van betekenis was.

Het overgrote deel der Hindostanen zocht een zelfstandig bestaan in het semi-commerciële klein-landbouwbedrijf en de melkveehouderij, hoewel ook de vrije en ambtelijke beroepen enige aantrekkingskracht op het jongere geslacht begonnen uit te oefenen. 
De steunregeling bleek fnuikend te zijn voor de werklust en dreigt voor een samenleving waarin velen van mening zijn, dat de staat verplicht is voor hun welzijn zorg te dragen, zonder enige tegenprestatie te eisen, in financiële en psychologische zin een ondragelijke last te worden.

$\mathrm{Om}$ al deze redenen werden de vooruitzichten van een verzorgende en importvervangende of een export-industrie voorshands niet hoog aangeslagen. Slechts aan enkele arbeidsextentieve en daardoor veelal kapitaalsintensieve bedrijven, die de schaars aanwezige grondstoffen zouden kunnen verwerken tot hoogwaardige produkten werden betere kansen gegeven.

Aangezien 's Lands financiële en economische positie reeds in te sterke mate afhankelijk was van de mijnbouw, die zich hoofdzakelijk toelegde op de winning van bauxiet - in I95I kwam $30 \%$ van de ontvangsten op de gewone dienst en $83 \%$ van de uitvoerwaarde op rekening van dit erts - en deze bedrijfstak slechts aan een klein deel van de bevolking een bestaan verschafte, bleef er geen andere weg open dan de land- en bosbouw als hefboom te gebruiken voor de verdere ontwikkeling van het land, hoewel werd ingezien, dat de snelle bevolkingsaanwas zonder een gelijktijdige industriële ontplooiing lang niet volledig zou kunnen worden opgevangen.

Voor Suriname lag deze benadering van het probleem overigens voor de hand, niet alleen omdat omstreeks I950 in de agrarische sector ruwweg $80 \%$ der mannelijke beroepsbevolking werkzaam was, maar ook omdat het gemiddelde inkomen per hoofd, in verband met de geringe arbeidsproduktiviteit zeer aanzienlijk lager was dan in de andere sektoren van het maatschappelijk bestel.

Dit vormde een der voornaamste oorzaken van de steeds verder gaande urbanisatie, welke de economie van het land dreigde te ontwrichten. Immers moesten in de hoofdstad niet alleen extra voorzieningen worden getroffen op sociaal gebied, maar orde en rust dreigden te worden verstoord, aangezien de zeden en gewoonten van de in geen enkel familieverband levende nieuwkomers met hun marginaal inkomen als ongeschoold arbeider, door de stedelijke sfeer zeer ongunstig werden beïnvloed (5). Evenmin verruimde deze situatie de afzet van de landbouwprodukten aangezien vele stadsbewoners, mogelijk uit prestigeoverwegingen, importartikelen boven de produkten van het eigen land verkozen.

Bovendien waren de economen vrijwel algemeen van mening, 
dat de verhouding van de agrarische en industriële prijzen zich in de komende jaren gunstig zou blijven ontwikkelen, waardoor de 'terms of trade' voor Suriname, als leverancier van ruwe agrarische en minerale grondstoffen, veel beter zouden zijn en voorlopig ook zouden blijven, dan vóór de tweede wereldoorlog. Maar de moeilijkheden welke eerst moesten worden overwonnen, waren vele.

Door het moeilijk op gang komen van de industrie vervielen allereerst de voordelen welke normaliter voortspruiten uit de bekende wisselwerking tussen deze bedrijfstak en de landbouw terwijl de kleine, spoedig overvoerde lokale markt en de beperkte afzetmogelijkheden in het buitenland een ernstig beletsel vormden voor een verhoging van de landbouwproduktie. De moeilijkheden met betrekking tot de export, waren niet alleen van dezelfde aard als die welke voor de industrie golden, maar hielden voorts nog verband met het kleine en bovendien jaar op jaar sterk wisselende volume van het voor uitvoer in aanmerking komende deel der produktie en met de minder goede kwaliteit der produkten.

Dit laatste was niet uitsluitend een gevolg van een minder zorgvuldige nabehandeling van de oogst, maar hing tevens samen met bepaalde aan de verbouwde variëteit der cultuurgewassen inhaerente erfelijke eigenschappen.

Tenslotte konden de omliggende landen op scherp concurrerende wijze dezelfde agrarische grondstoffen leveren, daartoe in staat gesteld door lagere kostprijzen, geringere vrachtkosten in verband met de vaak gunstiger ligging ten opzichte van de wereldscheepvaartroutes, en handelsafspraken van verschillende aard.

De geringe omvang van de landbouwproduktie was enerzijds toe te schrijven aan het kleine landbouwareaal, anderzijds aan de middelmatige opbrengsten per ha, welke voornamelijk een gevolg waren van enkele minder gunstige facetten van bodem en klimaat.

Wat de bodemgesteldheid betreft zij aangestipt, dat het geleidelijk uit de kustvlakte oprijzende hoogland, dat bijna $85 \%$ van het geografisch oppervlak inneemt, uit gronden bestaat die in chemisch, soms ook in fysisch opzicht als marginaal zijn aan te merken.

Slechts met toepassing van uitgebreide en kostbare technische maatregelen, zouden zij permanent voor landbouwdoeleinden kunnen worden benut, de steilere terreinen uitsluitend voor boomvormige cultuurgewassen of produktiebos met het oog op het erosiegevaar, de vlakkere mede voor veeweiden t.b.v. een intensieve veehouderij. Ontsluiting en ontginning van de gronden in dit praktisch onbewoonde, afgelegen en deels met zwaar tropisch loofhoutbos begroeide gebied, zouden bovendien veel arbeid en kapitaal vergen. 
Bij de gangbare produktiemethoden bood dit gebied weinig aantrekkelijks, noch voor de groot- noch voor de klein-landbouw zover deze ook voor de markt wenste te produceren. Daarenboven oefenden de min of meer autonome dorpen der bosnegers over enorme uitgestrektheden eigendomsrechten uit, die bij een eventuele exploitatie dezer gronden door derden, eerst moesten worden afgekocht. De landbouwactiviteit beperkte zich dan ook tot de kuststrook, een door grote rivieren doorsneden vlakte, die ten opzichte van het verkeer, in het bijzonder te water, gunstiger was gesitueerd. Aangezien dit circa $10.000 \mathrm{~km}^{2}$ grote, volkomen vlakke en in natuurlijke staat moerassige gebied gemiddeld $\mathrm{I} \mathrm{m}$ onder zeeniveau is gelegen, behoudens de series strandwallen, die vooral in het centrum en Oosten worden aangetroffen, waren uitgebreide inpolderings- en ontwateringswerken noodzakelijk, alvorens hier de landbouw kon worden beoefend. De daarvoor nodig zijnde grote investeringen waren slechts verantwoord indien met aanvaardbare kosten en gering oogstrisico, hoogwaardige, weinig in prijs fluctuerende gewassen zouden kunnen worden verbouwd.

Zowel in fysisch als in biologisch opzicht zijn deze zware zeekleigronden, die gekenmerkt worden door een uiterst geringe doorlaatbaarheid en zeer hoge grondwaterstand, voor alle gewassen ongunstig behalve voor een moerasplant als rijst.

De kuststrook leende zich dus het best voor de verbouw van rijst, een gewas, dat in de tropen echter nimmer de aandacht had van de ondernemingslandbouw en in de subtropen slechts op commerciële schaal wordt geteeld als onderdeel van een meerjarig rotatieplan, met behulp van uitgebreide prijsregelingen van de Overheid.

Suikerriet, bananen en struikvormige gewassen als citrus, koffie, cacao, die per hectare en per man een hogere opbrengst gaven dan rijst, werden in de vlakte wel verbouwd doch vereisten voor succes veel uitgebreider en kostbaarder landbouwmaatregelen. Niettegenstaande deze maatregelen verbleven zij toch in een onnatuurlijk milieu, wat tot uitdrukking kwam in een grote gevoeligheid voor ongunstige weersinvloeden en voor ziekten, waarvan betrekkelijk lage, sterk wisselende produkties per ha het gevolg waren.

Bovendien rustten ook hier op het overgrote deel der braakliggende, zowel op direkt als niet direkt exploiteerbare complexen, eigendomsrechten (onverdeelde boedels), die nimmer werden geannuleerd. Deze gronden konden daarom nog niet in de boezem van het domein worden teruggebracht.

Een andere ongunstige factor voor de landbouw vormt het klimaat, dat gekenmerkt wordt door een wisselvallig intreden der seizoenen en een zeer onregelmatige regenval.

De nadelen van een onbetrouwbare regenval zouden weliswaar soms door bevloeiing kunnen worden ondervangen, maar daartoe waren lange en zeer duur in onderhoud zijnde aanvoerleidingen nodig, aangezien de aftappunten in de getij-rivieren ver stroomopwaarts moeten worden gezocht, om het gehele jaar over zoet water te kunnen beschikken. Weliswaar zou de zoutgrens in verschillende grote rivieren stroomafwaarts kunnen worden verplaatst door het afvoerdebiet te reguleren, maar dit ging met zeer zware kosten gepaard. Door het ontbreken van enig verhang waren zowel voor irrigatie als voor drainage kostbare pompinstallaties nodig; 
slechts in een $5 \mathrm{~km}$ brede strook langs de rivieren kon het water op meer natuurlijke wijze worden geloosd,

De middelmatige jaarlijkse regenval is bovendien verdeeld over een groot aantal regendagen, waardoor in normale jaren een uitgesproken droge tijd ontbreekt, met het gevolg, dat ziekten, plagen en onkruid zich het gehele jaar ongestoord kunnen ontwikkelen, waardoor het oogstrisico vergroot en de exploitatie-rekening extra belast wordt.

De vele regendagen deden bovendien de veldwerkzaamheden vaak stagneren waardoor de toch al lage arbeidsproduktiviteit van de landman verder werd verlaagd, terwijl in het geval er zware machines werden gebruikt, het aantal draaiuren te gering werd voor een lonende exploitatie.

Verschillende aspecten van de bodem en het klimaat van Suriname waren dus bepaald minder gunstig voor de landbouw en waren oorzaak, dat het verschijnsel der afnemende meer-opbrengsten zich snel openbaarde, hetgeen wil zeggen, dat de rentabiliteitsgrens van technische maatregelen ter verhoging van de landbouwproduktie en van de arbeidsproduktiviteit spoedig wordt bereikt.

\section{DE OPZET VAN HET TIENJARENPLAN}

Uit de inleiding zal het duidelijk zijn geworden, dat het ontwikkelingsplan in feite een tienjarig publiek investeringsplan was, daar de beschikbare fondsen overwegend dienden voor het uitvoeren van werken met een openbaar karakter welke tot de economische en sociale ontwikkeling van het land bijdroegen en voor het treffen van voorzieningen op het gebied van het fundamentele onderzoek. Deze investeringen droegen een éénmalig karakter, zodat geregeld wederkerende uitgaven ten laste van 's Lands gewone begroting dienden te komen.

Slechts in het geval, dat gedurende enige jaren vol te houden uitgaven, welke moeilijk op de gewone begroting waren te brengen, tot een permanente verbetering van een welvaartsbron zouden leiden, kon van deze stelregel worden afgeweken.

Vanzelfsprekend moest de buitengewone begroting worden beperkt, opdat de monetaire en financiële stabiliteit van het land niet in gevaar zou worden gebracht. Uiteraard kon zij niet volledig worden gemist aangezien anders kapitaalsuitgaven, welke niet ten laste van de plangelden konden worden gebracht, bv. vervangingsinvesteringen, niet zouden kunnen worden gefinancierd.

Het Tienjarenplan' had een drieledig doel, nl. een regelmatige verhoging van het reëel inkomen van de bevolking per hoofd, verbe- 
tering van de betalingsbalans en verbreding van de economische basis van het land waardoor ook de werkgelegenheid zou worden verruimd. Deze doelstellingen zouden moeten worden gerealiseerd met behoud van het bestaande niveau der sociale voorzieningen en zonder verstoring van het monetaire evenwicht.

De projekten, die voor opneming in het plan in aanmerking kwamen, moesten aan zekere criteria voldoen, waarbij niet over het hoofd werd gezien, dat het hier eigenlijk ging om een duurzame verbetering van de economische en socio-culturele structuur van de volkshuishouding, o.m. door aan de structurele werkloosheid een einde te maken, en niet primair om een maximumverhoging van het nationaal inkomen of een zo groot mogelijk exportoverschot. Bovendien behoefde het plan voor succes een reeks van aanvullende en ondersteunende financieel-monetaire, fiscale en legislatieve maatregelen van de overheid.

DE PRIMAIRE SEKTOR

\section{DE LANDBOUW}

Ogenschijnlijk was de keuze niet moeilijk aan welke bedrijfsvorm, de bevolkings- of de ondernemingslandbouw, de meeste aandacht zou moeten worden geschonken, daar in I950 $90 \%$ van de totale waarde der landbouwproduktie voor rekening kwam van de kleinlandbouw en slechts I0\% van de plantages. Het aandeel van een handjevol plantages met een beplant areaal van slechts 5000 ha in de landbouwexport van Sf. $2,7 \mathrm{mln}$ bedroeg in 1950 echter $40 \%$.

Aangezien in verband met de plandoeleinden de voorkeur moest uitgaan naar projecten, welke de beste kans boden op een exportverhoging, tenzij dringende belangen van sociale of economische aard een afwijkende handelwijze rechtvaardigden, diende te worden onderzocht in hoeverre het mogelijk zou zijn om de eens zo welvarende ondernemingslandbouw nieuw leven in te blazen. Dit onderzoek wees uit, dat de vooruitzichten van deze landbouwvorm weinig rooskleurig waren, in verband met het beperkte arbeidsreservoir, het relatief hoge loonpeil en de onvoldoende kapitaalsvoorziening.

Deze structurele tekortkomingen welke met de minder gunstige facetten van bodem en klimaat, oorzaak waren van de lage gemiddelde produkties per ha en hoge kostprijzen, konden meestal niet worden ondervangen.

Wat de arbeidsvoorziening bij de teelt van overjarige gewassen 
bemoeilijkte was de onmogelijkheid om de oogst te mechaniseren, terwijl het gebruik van grotere machines bij de veldwerkzaamheden in het door kanalen en sloten doorsneden gebied, tot een minimum beperkt bleef.

De hoge kostprijs was oorzaak, dat de concurrentie met de omliggende landen die eenzelfde landbouwpatroon hadden en welker economie goeddeels afhing van de uitvoer van één produkt, zeer zwaar viel, temeer daar deze landen voor geen enkel middel terugdeinsden om hun export gaande te houden. Pogingen om door samenwerking grotere produktieenheden te vormen waardoor leiding en andere produktiefactoren op doelmatiger wijze hadden kunnen worden gecombineerd, mislukten.

$\mathrm{Om}$ al deze redenen werd gemeend, dat aan de ontwikkeling van de klein-landbouw de meeste aandacht behoorde te worden geschonken.

In de komende jaren zou dan ook moeten worden gestreefd naar de vorming van een krachtige, economisch zelfstandige boerenstand die nog altijd de ruggegraat van elke volkshuishouding vormt en daaraan ook de nodige stabiliteit geeft, indien men voor de afzet der produkten niet uitsluitend aangewezen is op de wereldmarkt. Zij moest in staat worden gesteld zo volledig mogelijk te voorzien in de binnenlandse vraag naar voedsel en grondstoffen tegen ook voor de consument aanvaardbare prijzen en bovendien een tastbare bijdrage leveren in de export. Dit laatste vereiste echter een geregelde levering van in kwantiteit en kwaliteit weinig fluctuerende produkten, kennis van de handelsusances op de Westerse markten, en begrip voor de wisselvalligheid der inkomsten. In verband hiermede was het Planbureau van oordeel dat deze bijdrage voorshands niet belangrijk kon zijn terwijl het de tijd nog niet gekomen achtte voor een exploitatiewijze welke de voordelen van het groot- en kleinbedrijf combineerde, daar de daartoe vereiste instelling bij de beoefenaars van deze landbouwvormen niet aanwezig was.

Daarom werd het Wageningenprojekt, dat immers vooral een exportdoel nastreefde, in het Tienjarenplan opgenomen, hetgeen geoorloofd leek omdat door intensief en geconcentreerd onderzoek de technische moeilijkheden op dit bedrijf in de eerstkomende jaren goeddeels konden worden opgelost en de economen voorspelden, dat de rijstprijzen op een hoog niveau zouden blijven.

Uit de beschikbare summiere en niet steeds ten volle betrouwbare statistische gegevens werd geconcludeerd, dat in I95I het 
gemiddelde bruto-jaarinkomen van de landbouwbeoefenaar nauwelijks Sf. $35^{\circ}$ bedroeg tegen Sf. $375^{\circ}$ en Sf. $875^{\circ}$ van een arbeider in de industrie en mijnbouw.

Aangezien de gemiddelde omvang der echte klein-landbouwbedrijven welke zijn gelegen tussen $0,8-8$ ha, ca. 2,4 ha bedroeg, lag het voor de hand de voornaamste oorzaak van het geringe boereninkomen tezoekenin een wanverhouding tussen het beschikbare oppervlak cultuurgrond en het aantal personen dat daarop een bestaan moest vinden. Voorts in de eenzijdige beplanting met rijst, een gewas dat immers gekenmerkt wordt door een ongunstige arbeidsverdeling gedurende de groeiperiode, waarvan een aanzienlijke verborgen werkloosheid en een geringe arbeidsproduktiviteit het gevolg waren. Edoch bleek, dat van de per gezin ter beschikking staande grond slechts $60 \%$ bewerkt werd, hoewel dit percentage sterk varieerde naar streek, rasgroep en beschikbaar areaal. Het niet geheel benutten der bouwvelden was hoofdzakelijk het gevolg van de onoordeelkundige uitgifte en ontginning der gronden in het verleden, welke tot lintbebouwing langs de rivieren en hoofdwegen leidden waardoor èn de ontsluiting èn de waterbeheersing van het gehele perceel onmogelijk werden.

De produktie bleef daardoor in totaal en per hectare ver beneden de potentiële mogelijkheden. Bovendien vormden de bedrijven lang niet altijd een aaneengesloten geheel, maar bestonden uit verschillende, soms ver uit elkaar liggende percelen.

Door verbetering der cultuuromstandigheden en ruilverkaveling zou een doelmatiger bodemgebruik mogelijk worden, waardoor de arbeidsproduktiviteit niet onbelangrijk kon worden opgevoerd en de verbouw van gewassen als soya en inheemse boonsoorten, hetzij op sawahs na de rijst, of als hoofdgewas op de zand- en schelpritsen, wellicht ook ingang kon vinden.

De keuze van soya als nagewas van sawahrijst steunde in de eerste plaats op voor de toekomst zeer goed beoordeelde afzetmogelijkheden in Europa (6) en op de in Indonesië opgedane ervaring, dat dit gewas op extensieve wijze kon worden verbouwd ook op zeer zware gronden, mits gezorgd kon worden voor een gunstige afwatering en gelet werd op een juiste planttijd. Om deze redenen leende deze teelt zich bij uitstek voor klein-landbouwers die immers in ruime mate over de tijd beschikten om aan deze voorwaarden de nodige aandacht te besteden. Of in Suriname de verbouw in het groot, dus met behulp van machines mogelijk was, zou door langdurig onderzoek moeten worden uitgemaakt.

Een verdere verhoging van de produktiviteit kon echter slechts worden verkregen door uitbreiding van het bedrijfsareaal, wat 
landaanwinning noodzakelijk maakte, maar dit zou nimmer op een schaal kunnen geschieden, die aan de discrepantie tussen stedelijk en landelijk inkomen ook maar bij benadering een einde makkte. Dit zou de beschikbare middelen ver te boven gaan, terwijl het economisch inzicht en de kennis van de klein-landbouwers nog volkomen ontoereikend waren om grote, noodwendig gemotoriseerde en op commerciële leest geschoeide bedrijven, te beheren.

Bovendien drong zich de vraag op, in hoeverre in een agrarisch dicht bevolkt land als Suriname, waar landaanwinning met zware kosten gepaard gaat, de werkgelegenheid buiten de landbouw uiterst beperkt en kapitaal schaars en duur is, motorisatie van de landbouw zowel in privaat als nationaal opzicht, verantwoord is.

Bij de beoordeling van de betekenis van de landaanwinningsprojekten voor de nationale economie mocht echter niet over het hoofd worden gezien, dat hun fiscale rentabiliteit vrijwel zeker onvoldoende was, ook al zou een deel van het geĩnvesteerde kapitaal door schenkingen worden verkregen, terwijl evenmin diende te worden vergeten, dat in Suriname het multiplier-effect van dergelijke projekten, inzonderheid ten aanzien van de werkgelegenheid vrij gering was, in verband met de zeer hoge importquota van het nationale inkomen. Schier alle materiaal dat bij een polderprojekt werd verbruikt moest immers worden geimporteerd: machines, onderdelen, brandstoffen, draineerbuizen, cement, etc., terwijl de uitbetaalde lonen doorgaans voor een flink deel aan ingevoerde verbruiksgoederen werden besteed.

Over de economische mogelijkheden van motorisatie van de groot-landbouw moest het oordeel voorlopig worden opgeschort, maar voor de klein-landbouw leken zij uiterst beperkt. De grote kracht van het kleine, vaak nog niet volledig in de geldhuishouding opgenomen gezinsbedrijf school immers juist in de geringe kapitaalsinvestering en de lage produktiekosten, waarvan het voornaamste onderdeel, de arbeid, niet in rekening werd gebracht, zover door het gezin zelf gepresteerd. Hierdoor bleef de landbouwer in staat om ook bij een dalende conjunctuur nog geruime tijd, naar zijn inzicht lonend, te blijven produceren en zijn bedrijfsplan aan de veranderde omstandigheden aan te passen. Dit laatste, de flexibiliteit van het bedrijf dus, zou door motorisatie worden aangetast, omdat de geteelde gewassen aan het gebruik van machines moeten zijn aangepast en niet op korte termijn door andere kunnen worden vervangen. Aan het bezwaar 
van de grote kapitaalsinvestering zou echter door coöperatieve samenwerking wellicht kunnen worden tegemoet gekomen.

De uitbreiding en sanering van het landbouwareaal diende naar het oordeel van het Planbureau geleidelijk plaats te grijpen, omdat een aanzienlijke verhoging van de agrarische produktie slechts verantwoord was, indien de produkten te allen tijde, hetzij lokaal dan wel elders of beide, een lonende afzet konden vinden.

De moeilijkheden waarvoor de export stond werden reeds besproken, terwijl de binnenlandse afzet van verschillende factoren afhing, o.a. van de inkomens en prijselasticiteit t.a.v. essentiële en niet-essentiële voedingsmiddelen, waaromtrent men zich echter toentertijd geen duidelijke voorstelling kon maken.

Op het nieuwe en gesaneerde land zou in verband met dit alles slechts worden gestreefd naar de vorming van gezinsbedrijven van 4 ha, omdat een in I940-r945 gehouden oriënterend onderzoek (geen recentere gegevens waren beschikbaar) nl. had uitgewezen, dat onder gemiddelde omstandigheden van bodemvruchtbaarheid, ligging, produktiepatroon (vnl. rijstteelt), produktiewijze, prijzen, behoeftenpeil en vakbekwaamheid der landbouwers, een bedrijfje van deze omvang aan een normaal boerengezin niet alleen een zelfstandig bestaan waarborgde, maar het ook in staat stelde om op bescheiden wijze tot sparen over te gaan.

De produktiviteit zou dan echter moeten worden verhoogd door intensivering van het bouw- en bedrijfsplan. In het tekort aan eigen mankracht, dat reeds in een bedrijf van deze omvang op bepaalde tijden aan de dag trad, ook al konden enkele arbeidstoppen door wederzijds hulpbetoon worden afgevlakt, diende met behulp van veetractie te worden voorzien. Het vee kon bij een doelmatige stalverpleging daarnevens de functie van mestleverancier vervullen. Bovendien zouden de ernstige verliezen welke werden geleden als gevolg van de primitieve nabehandeling en opslag der geoogste produkten kunnen worden beperkt, indien de Overheid op strategische punten goed geoutilleerde drogerijen en opslagplaatsen oprichtte.

Vanzelfsprekend kwamen gebieden met de grootste agrarische bevolkingsdichtheid, de sterkste generatiedruk en de minste werkgelegenheid buiten de landbouw, het allereerst voor landaanwinning in aanmerking.

Met betrekking tot de generatiedruk der mannelijke agrarische beroepsbevolking, deed zich echter de complicatie voor, dat zij bij de ver- 
schillende bevolkingsgroepen sterk uiteenliep. In het district Suriname bv., bedroeg zij bij de Hindostanen 3,6 tegen r,8 bij de Creolen en slechts o,9 bij de Javanen, bij welke groep sterke veroudering optrad, zodat men eerder van een vacuüm dan van een druk kon spreken. Dit betekende, dat in een gebied waar de Hindostanen de overhand hadden, landaanwinning noodzakelijker was en op groter schaal zou moeten plaats hebben, dan daar waar de Javanen in de meerderheid waren, die genoegen namen met een bedrijf van veel kleiner omvang in verband met hun economische instelling en de geringere gezinssterkte, die gemiddeld 5.0 personen bedroeg tegen 7.4 bij de Hindostanen (7).

In dit licht bezien, had met landaanwinning het eerst in het distrikt Suriname moeten worden begonnen, hoewel onder de invloed der stadssfeer de neiging van de boerenzoons om in de landbouw hun hoofdbestaan te zoeken, minder sterk op de voorgrond trad dan elders.

In verband met de trek naar de stad, die zich vooral bij de jongere generatie openbaarde, ook al omdat zij onder de druk van het vaderlijk gezag uit wilden en in de overtuiging dat de werklozen in de hoofdstad voor polderwerk ongeschikt waren, werden echter juist de ver van Paramaribo, in het Westen van het land gelegen distrikten uitverkoren, waar voldoende ruimte en bevloeiingsmogelijkheid aanwezig waren.

De verstedelijking van een onevenredig deel der bevolking zou door een krachtige sanering der levensomstandigheden op het platteland verder moeten worden afgeremd.

Het landbouwkundig onderzoek beperkte zich niet tot bodemkundige vraagstukken, hoewel zij de hoofdschotel vormden, aangezien een juiste bodembestemming, een doeltreffend grondgebruik en een daarbij passende bedrijfsinrichting (8) zonder voorafgaand gedegen onderzoek onmogelijk waren, maar betrok daarin problemen, welke betrekking hadden op de hydrologische, landbouw-technische, economische, demografische, sociologische en legislatieve produktieomstandigheden.

Het onderzoek dat streeksgewijs door het Bureau Landelijke Opbouw (B.L.O.) moest worden ingesteld, beoogde in feite vast te stellen, welke produktiemiddelen zouden moeten en kunnen worden versterkt, om de landbouwers in staat te stellen zich tot een hoger welvaartsniveau op te werken. Onder streek werd een gebied verstaan, waar de geografische en sociografische milieufactoren, alsmede de produktieomstandigheden en het daarmee verband houdende bedrijfstype een zekere mate van uniformiteit vertoonden.

$\mathrm{Bij}$ de organisatie van het Bureau bleek hoe moeilijk het was om in de 
gegeven omstandigheden tot een doeltreffende werkwijze te komen. Immers had dit orgaan een onderdeel moeten vormen van het Planbureau, doch de toenmalige Landsminister van Landbouw, Veeteelt en Visserij voerde daartegen het bezwaar aan, dat hij in dat geval geen voldoende invloed meer zou kunnen uitoefenen op het voornaamste deel van het landbouwbeleid, waarvoor hij en niemand anders verantwoordelijk was. Om dit bezwaar te ondervangen werd het B.L.O. als een zelfstandig directoraat aan zijn Departement toegevoegd, een oplossing welke in de volgende jaren niet ideaal bleek te zijn,

Wat de uitvoering van de projekten betrof, zou de meest efficiënte werkwijze zijn geweest om de S.M.L. hiermee te belasten.

Deze organisatie beschikte immers over een uitgebreid, aan het specifieke Surinaamse polderwerk aangepast machinepark met een daarbij behorend reparatie-atelier en had, dank zij het Wageningen-projekt, op dit gebied reeds een ervaring verworven, waarop geen andere particuliere aannemingsmaatschappij of overheidsinstantie kon bogen. Bovendien had door samenwerking met een der grote Nederlandse ontginningsmaatschappijen de doelmatigheid nog verder kunnen worden verhoogd, waarmede niet alleen een Surinaams maar ook een Nederlands belang zou zijn gediend, daar deze maatschappijen met de hier opgedane ervaring hun activiteiten wellicht met succes op andere delen van Zuid-Amerika hadden kunnen richten.

Overwegingen van politiek-sociale aard, welke ook verband hielden met het werkloosheidsprobleem, dwongen echter om deze werken of door het Departement van Openbare Werken ò bij openbare inschrijving door plaatselijke aannemingsmaatschappijen te doen uitvoeren. Geen hunner was daarvoor echter voldoende geoutilleerd.

\section{DE VEETEELT}

De veestapel van Suriname, die in I950 op 5000 stuks melkvee en 30.000 trekdieren werd geschat, bestond overwegend uit runderen.

Het z.g. Creoolse melkvee, een uitermate heterogeen veeslag produceerde mede door de slechte voeding, onvoldoende vlees en melk voor de binnenlandse behoefte, waardoor een belangrijke invoer van zuivelprodukten en vleesconserven noodzakelijk werd. Alleen reeds om deze import overbodig te maken zou de produktie aanzienlijk moeten worden opgevoerd, maar nog sterker indien rekening werd gehouden met het bevolkingsaccres en het streven om de hoeveelheid dierlijk eiwit in het dagelijks menu te verhogen.

Door verbetering van het veeslag door kruising met een te importeren hoogwaardig ras, betere verzorging en uitbreiding van de veestapel zou getracht worden de produktie op te voeren.

In het kader der landelijke opbouwprojekten diende derhalve de nodige aandacht te worden besteed aan de verbetering der 
bestaande veeweiden en stallingen, terwijl op de Landsboerderij zou worden onderzocht, op welke wijze de melkveehouders hun produktie rendabel konden verhogen.

Aangezien werd aangenomen dat de motorisatie van de landbouw in de komende jaren slechts in langzaam tempo zou voortschrijden, moest ook een trekvee-stapel van voldoende omvang en kwaliteit in stand worden gehouden.

De eierproduktie zou evenzo door uitbreiding en verbetering van de pluimveestapel alsmede een rationelere voeding kunnen worden verhoogd.

Het veeteeltprojekt had echter in sterke mate een experimenteel karakter.

\section{DE VISSERIJ}

Van de geschatte visconsumptie van I2,5 $\mathrm{kg}$ per hoofd per jaar was nauwelijks de helft afkomstig uit eigen vangst. Relatief aanzienlijke hoeveelheden visconserven moesten daarom worden ingevoerd. Het verbruik in de hoofdstad van verse vis werd enerzijds geremd door de bestaande voedingsgewoonten anderzijds door de prijs, welke in verhouding tot die van de ingevoerde conserven, hoog was. Dit laatste werd niet alleen toegeschreven aan een onvoldoende aanvoer maar ook aan de monopolistische praktijken van de marktvrouwen.

Het visserijprojekt beoogde derhalve niet alleen de produktie te verhogen maar ook de vishandel in betere banen te leiden, waarmede zowel het belang van de producent als van de consument werd gediend. Aangenomen werd, dat de produktie van de binnenvisserij met de meeste kans op een spoedig succes, kon worden verhoogd, waartoe de outillage van de kunstmatige en natuurlijke zoet- en brakwatervisvijvers en de vismethoden verbeterd dienden te worden, met behulp van credieten in geld en/of natura.

De handel kon worden gesaneerd door in de voornaamste visserijcentra voorzieningen te treffen voor een tijdelijke opslag van vis, voor een snel transport naar de hoofdstad en door de organisatie van een visafslag.

Een grondig technisch en economisch vooronderzoek zou moeten uitwijzen hoe ook de produktie van de kust- en zeevisserij op een hoger peil zou kunnen worden gebracht. Hoewel zeer kostbaar, was een dergelijk onderzoek alleszins verantwoord omdat de zeevisserij wellicht een bijdrage in de export zou kunnen leveren. 
Vroeger werd jaarlijks nog een grote hoeveelheid garnalen in gedroogde vorm naar Nederland verscheept, maar deze handel verliep, enerzijds door een scherpe prijsval, anderzijds door allerlei technische moeilijkheden die de garnalenvisserij ondervond. Een onderzoek zou moeten uitwijzen of deze bezwaren waren te ondervangen en of andere markten konden worden gevonden.

De zeevis van goede kwaliteit zou bovendien in verschillende vormen deels voor uitvoer kunnen worden bestemd, terwijl de gladvis die de bevolking van het Caraïbische gebied uit bijgeloof niet wenst te consumeren, de grondstof kon vormen voor een lokale industrie van vismeel.

Het risico aan de zeevisserij verbonden, de grote kapitaalsinvestering in schepen, ijsvoorziening en koelinstallaties, alsmede de weinige bekendheid der vissers met deze visserijvorm rechtvaardigden echter een voorzichtige benadering van het probleem.

DE BosBouw

Niettegenstaande het bosbezit van Suriname benoorden de 4de breedtegraad, het meer toegankelijke deel van het land dus, 4,6 mln ha omvatte, bedroeg in $195^{\circ}$ de produktie uitgedrukt in rondhout nauwelijks $130.000 \mathrm{~m}^{3}$, waarvan $15 \%$ bestond uit schilhout en $85 \%$ uit vooral harde, zware houtsoorten, bestemd voor palen en voor de bouwnijverheid. Ook al werd in aanmerking genomen dat van de 200 soorten die het Surinaamse loofhoutbos bevatte, er slechts circa 20 handelswaarde hadden, dan stond deze houtoogst toch in generlei verhouding tot de potentiële mogelijkheden.

De oogst was voor de helft afkomstig van de bevolking, die slechts tot kap overging indien de geldbehoefte daartoe dwong, de andere helft van houtmaatschappijen welke, behoudens enkele uitzonderingen, hun uitgestrekte concessies op kapitaalsextensieve wijze exploiteerden. Door de onvoldoende ontsluiting van deze percelen waren zij, evenals de bevolking, voor de afvoer van het hout aangewezen op vlotbare waterlopen, terwijl de uitsleep meestal met handkracht plaatsgreep. Deze factoren leidden tot lintkap langs de rivieren en kreken, waarbij de meer naar binnen gelegen arealen onberoerd bleven. In de droge perioden hadden vele waterlopen echter een te gering debiet, waardoor vlotten onmogelijk werd. Het gevolg hiervan was een onvoldoende leveringszekerheid, waardoor de activiteiten van de houtindustrie en handel werden beperkt.

Om in dit alles verbetering te brengen was het noodzakelijk, dat de concessionarissen de exploitatie concentreerden op de 
meest waardevolle delen van hun perceel en de houtafvoer op doeltreffender wijze organiseerden. Deze perceelgedeelten moesten minstens $50 \mathrm{~m}^{3} / \mathrm{ha}$ waardevol hout bevatten terwijl de terreingesteldheid van dien aard diende te zijn, dat moderne gemechaniseerde methoden bij kap, uitsleep en vervoer konden worden toegepast.

In het kader van het Tienjarenplan beoogde het Boswezen deze waardevolle complexen, tot een totaal van 500.000 ha, op te sporen, die bij een omlooptijd van 80 jaar en een jaarlijkse kap op 6000 ha, $300.000 \mathrm{~m}^{3}$ per jaar konden produceren. Met inbegrip van de produktie der bevolking kon de jaaropbrengst derhalve $365.000 \mathrm{~m}^{3}$ worden. Deze complexen moesten uiteraard worden ontsloten door hoofdwegen, welke de bosbestanden tussen vlotbare waterlopen toegankelijk maakten.

Voor de ontsluiting van het moerasbos, dat o.m. het voor de triplexfabricage zo belangrijke 'Baboen' bevatte, was de aanleg van kanalen noodzakelijk.

Aan het bosbouwkundig onderzoek zou eveneens zeer veel aandacht worden geschonken.

Tot nu toe waren slechts van een gering aantal houtsoorten de gebruiksmogelijkheden bekend, niet alleen voor allerhande houtwerk maar ook voor schilhout, pulp, board etc. Door hierin verandering te brengen kon de produktie in totaal en per ha worden opgevoerd, hetgeen ook op de kostprijs een gunstig effect zou hebben. Een laboratoriumonderzoek had reeds uitgewezen, dat uit een mengsel van sommige Surinaamse loofhoutsoorten bij een speciale behandeling, een pulp kon worden verkregen, die bruikbaar was voor pakpapier, golfkarton en na bleking zelfs voor schrijf- en drukpapier.

Vanzelfsprekend moest het produktiebos in stand worden gehouden door houtteeltkundige maatregelen. Bij natuurlijke verjonging werd uiteraard gestreefd naar een bosbestand waarin de meest waardevolle houtsoorten domineerden, hetgeen echter een uitgebreide ecologische voorstudie vereiste.

Cultuuraanleg op grote schaal vereiste allereerst een diepgaand onderzoek naar de technische en later naar de economische mogelijkheden van verschillende waardevolle inheemse en exotische houtsoorten in homogene aanplantingen. (9) Speciaal ten aanzien van de in Midden-Amerika autochtone Pinus caribaea koesterde men grote verwachtingen, omdat deze naaldboom geringe eisen stelde aan de bodemvruchtbaarheid, in de tropen zeer snel groeide en daardoor op jeugdige leeftijd kapbaar was. 
Het naaldhout levert zoals bekend de beste grondstof voor de papierfabricage.

Tenslotte vereisten de verbetering van het zeer lage zaagrendement, de houtbewaring in de open lucht, het kunstmatig drogen van zachte en harde houtsoorten, de conservering met diverse chemicaliën etc. eveneens het nodige onderzoek.

Voorlichting op verschillend gebied was zonder dit onderzoek volstrekt onmogelijk en evenmin een gefundeerde propaganda in het buitenland voor het gebruik van Surinaams hout.

In Suriname zelf zou het gebruik van hout bij de huizenbouw moeten worden gestimuleerd. Na impregnering met chemicaliën zouden voor dit doel ook de verschillende minderwaardige houtsoorten die thans in de bosbestanden achterbleven, kunnen worden benut, terwijl de rentabiliteit van de voor export werkende zagerijen aanzienlijk zou kunnen worden verhoogd indien de plaatselijke markt voor de 2 de en lagere kwaliteiten hout kon worden verruimd. Temeer was dit van betekenis, daar vele Surinaamse houtsoorten op stam nogal wat gebreken vertoonden, waardoor het percentage Iste kwaliteit hout, dat bij verzaging van een blok werd verkregen, slechts 30 à $40 \%$ bedroeg, hoewel uit een later onderzoek bleek, dat dit percentage door een doeltreffender inrichting der zagerijen niet onbelangrijk kan worden verhoogd.

Het Boswezen was door combinatie van allerlei gegevens in staat om ten behoeve van de exploitanten bedrijfsplannen op te stellen, aan de hand waarvan de ondernemers niet alleen een nauwkeurige kostencalculatie konden maken, maar ook de leveringscapaciteit van hun bedrijf konden aanpassen aan de potentiële afzetmogelijkheden, waardoor het exploitatierisico sterk werd verminderd. Een moderne exploitatie van een bosbedrijf vereiste echter een zeer grote kapitaalsinvestering, waartoe lang niet alle ondernemers in staat waren. Daarom werd voor hen de mogelijkheid geopend voor geldelijke steun een beroep te doen op het nader te noemen 'industriefonds.'

Behalve een betere voorziening van de binnenlandse markt beoogde het bosbouwprojekt vooral ook het vergroten van de export van hout en houtprodukten, die in I950 inclusief bosprodukten als balata en wilde palmpitten een waarde vertegenwoordigde van ruim Sf. $3 \mathrm{mln}$, waarvan Sf. I, $8 \mathrm{mln}$ aan triplex. De sterke concentratie van de uitvoer van triplex op een enkel land, alsmede de overheersende rol die dit produkt in de totale houtuitvoer speelde, hield uiteraard een gevaar in zich. 
De mogelijkheid voor vergroting van de uitvoer van rond, vierkant, en gezaagd hout in het bijzonder naar Europa, werd echter slechts aanwezig geacht indien geconcurreerd kon werden tegen de grote Westafrikaanse en Z.O.-Aziatische houtleveranciers, waarbij niet alleen de vrachttarieven een grote rol speelden maar ook andere handelstechnische factoren als groter zaagrendement, geregelder levering, aantrekkelijker maten en gevarieerder gebruiksmogelijkheden.

Verruiming van het exportpakket werd daarom vooral gezien in de fabricage van veredelde houtprodukten en produkten als hardboard en spaanplaten. Het stond vast, dat een aantal Surinaamse houtsoorten die zich minder leenden voor bouwhout of verzaging, afzonderlijk of gemengd tot vezelplaten konden worden verwerkt. Omtrent de afzet daarvan tastte men echter nog in het duister. Gehoopt werd, dat spaanplaten of hardboard vooral in het Caraïbische gebied met zijn in brede lagen arme bevolking, en de gebruikelijke 'open' bouwwijze, een kans zouden maken. Vermoedelijk had een fabriek van spaanplaten de beste perspectieven, niet alleen omdat een hardboardindustrie een grotere investering vraagt, maar ook, omdat in het bijzonder de Europese markt reeds ruimschoots van hardboard is voorzien en in mindere mate van spaanplaten.

DE SECUNDAIRE SEKTOR

\section{INDUSTRIE}

Hoewel de grote betekenis van de industrie ten volle werd onderkend, was er om de reeds genoemde redenen weinig hoop op een snelle industriële ontwikkeling.

Wel werd in de verwerking van agrarische grondstoffen als hout, vis, vlees, melk, rijst, cocos, suiker, melasse, olie en vethoudende zaden, fruit, w.o. vooral citrus, een mogelijkheid gezien tot verdere industrialisatie, temeer waar verschillende afvalstoffen soms met voordeel konden worden verwerkt tot waardevolle produkten. Zo zou de afval van de reeds bestaande triplexfabriek en zagerijen kunnen worden benut voor spaanen vezelplaten; die van de rijstpellerijen voor veevoer etc.

Ook werden de vooruitzichten van enkele bedrijven, welke uitsluitend of grotendeels voor de binnenlandse markt voedingsmiddelen en consumptiegoederen fabriceerden uit locale of geïmporteerde grond- en hulpstoffen, niet al te ongunstig beoordeeld. Te denken viel aan een confectiebedrijf, bierbrouwerij, 
zeepziederij, leerlooierij, een verffabriek en aan de fabriekmatige bereiding van cocosolie en vruchtensappen.

Uit een onderzoek was reeds komen vast te staan, dat een op coöperatieve grondslag werkende vruchtensappen- en conservenfabriek levensvatbaar was, indien een geregelde en voldoende aanvoer van gezond fruit verzekerd was (ro). Evenzo bleken de perspectieven van een glas- en keramische industrie waarvoor de voornaamste grondstoffen aanwezig waren, gunstig te zijn, daar lokaal slechts 2 de kwaliteit bakstenen werden vervaardigd zodat alle andere keramische produkten moesten worden ingevoerd. Verwacht kon worden dat deze import snel verder zou stijgen in verband met de stijgende behoefte van de bouwnijverheid aan cement, metselstenen, dakpannen, vensterglas, plavuizen en van de landbouw aan draineerbuizen etc. In de omliggende landen viel een toenemende vraag naar vuurvast materiaal waar te nemen, zodat het Surinaamse produkt hier afzet zou kunnen vinden, temeer waar dit hoogwaardige produkt zware vrachtkosten kon verdragen en rechtenvrij kon worden ingevoerd (II). Op de enorme betekenis van een eigen aluminiumindustrie behoeft niet meer te worden gewezen. In het algemeen zouden verschillende van de genoemde industriële bedrijven de beste kans van slagen hebben als dochterinstelling van elders gevestigde ondernemingen.

Vanzelfsprekend diende de Overheid door fiscale maatregelen op verschillend gebied de vestiging van bedrijven te stimuleren en zou verder moeten worden zorggedragen voor een behoorlijk potentiëel aan geschoold personeel en voor een goede voorlichting aan alle nieuwkomers. Gelet op het bestaande, nog weinig gunstige industriële klimaat leek het echter voorshands niet waarschijnlijk, dat buitenlandse investeerders het ondernemersrisico volledig zouden aanvaarden. Pogingen om Nederlandse ondernemers te interesseren in een vruchtenverwerkings-, zuivelen keramisch bedrijf liepen alle dood.

Met behulp van een in het kader van het Tienjarenplan te stichten industriefonds, zou de Overheid echter in staat zijn om direct of indirect door te garanderen leningen, in het aanvangskapitaal te participeren. Haar aandeel kon, zodra het bedrijf levensvatbaar was gebleken, hetzij in kleine coupures aan binnenlandse investeerders of combinaties daarvan, worden afgestoten dan wel aan de moederondernemingen worden overgedaan, zoals o.a. dat bij de Surinaamse Houtmaatschappij (Bruynzeel) reeds lang geleden plaats had. 
Indien voor een bedrijf, dat voor de economische ontwikkeling van het land noodzakelijk wordt geacht, van particuliere zijde geen enkele belangstelling wordt getoond, ook niet voor een 'joint venture', zou de overheid zelf tot oprichting en exploitatie daarvan moeten overgaan, in het bijzonder wanneer de belangen van de grondstofleverancier sterk tegengesteld zijn aan die van de binnenlandse consument.

\section{MijNBOUW}

Aangezien het Surinaamse hoogland deel uitmaakt van het $\mathrm{zg}$. Braziliaanse schild, dat in structuur overeenkomt met de rijk gemineraliseerde Canadese en Scandinavische schilden, lag het uiteraard voor de hand te onderzoeken of in Suriname, behalve hoogwaardig bauxiet en laagwaardig ijzererts, ook economisch exploiteerbare afzettingen aanwezig waren van platina, koper, diamant, mangaan, kyaniet, beryl, columbiet, etc. van welke mineralen reeds indicaties waren aangetroffen.

Aangezien slechts door een systematische geologische kartering een inzicht kon worden verkregen omtrent de juiste opbouw van de bodem, werden op het minimumplan allereerst gelden uitgetrokken voor de voltooiing van de luchtkartering van de noordelijke helft van het land waarmede de K.L.M., in opdracht van het Welvaartsfonds, in 1947 een aanvang had gemaakt. Hierop aansluitend zou later aan genoemde maatschappij voor de zuidelijke helft van Suriname een zelfde taak worden opgedragen, welk werk ook voor het hieronder te noemen Brokopondoplan van eminente betekenis was.

Daar de stollingsgesteenten van het Surinaamse hoogland soms wel tot een diepte van $30 \mathrm{~m}$ verweerd zijn en veelal bedekt met zwaar oerbos, kon slechts aan de hand van de uit de luchtfoto's te vervaardigen topografische kaarten terrestrisch worden uitgemaakt of hier exploiteerbare ertsafzettingen aanwezig waren. De geologisch-mijnbouwkundige dienst was echter voor dit veldwerk te enen male onvoldoende uitgerust, zodat een krachtige uitbreiding daarvan werd voorgestaan.

Het mijnbouwkapitaal zou echter nooit kunnen worden aangetrokken, indien de bestaande mijnwetgeving niet grondig werd herzien. De rechten op het verkrijgen van concessies, de fiscale verplichtingen, de kwestie van afschrijving en transfer, en de winstverdeling dienden nauwkeurig vast te staan.

Werd inschakeling van het particuliere kapitaal reeds bij het opsporen van ertsen wenselijk geacht, ten aanzien van de bauxiet, 
die een allesoverheersende rol speelde in de Surinaamse economie, moest een uitzondering worden gemaakt. Het bauxiet-onderzoek zou door de Overheid moeten worden bekostigd om de resultaten later op de voordeligste wijze aan het aluminiumkapitaal ter beschikking te kunnen stellen. Laatstgenoemd onderzoek was urgent omdat de bekende exploiteerbare bauxietreserves in I95I slechts op 50 miljoen ton werden geschat, een voorraad die bij een export van 3 miljoen ton per jaar, in 17 jaar zou zijn uitgeput.

Was reeds om deze redenen het opsporen van nieuwe reserves noodzakelijk, temeer was dit het geval omdat het uitermate kostbare Brokopondoprojekt bij een jaarlijkse produktie van 40.000 ton aluminium c.q. I60.000 ton bauxieterts per jaar verbruikte. Bij een afschrijvingsduur van roo jaar zou dit enorm kapitaalsintensieve bedrijf over een reserve van I6 miljoen hoogwaardig en economisch transportabel erts moeten kunnen beschikken (I2).

De kyaniet-kwartsiet, waaromtrent men eertijds enige verwachtingen koesterde, bleek bij nader onderzoek van een zo geringe kwaliteit te zijn en de afzettingen lagen zo ver van de kust, dat exploitatie voor export onmogelijk werd geacht. Bij de binnenlandse fabricage van vuurvaste stenen (sillimaniet of mulliet) zou het echter wellicht nog een rol kunnen spelen.

De vestigingsvoorwaarden voor een hoogovenbedrijf in Suriname met het aanwezige laterietisch ijzererts als grondstof, werden ongunstig beoordeeld. Het erts was laagwaardig (ca 35\% $\mathrm{F}_{2}$ ), de benodigde cokes moest worden ingevoerd (smelting in kleine houtskool- of electrische ovens was onrendabel), de afstand van de vindplaats Donderbari tot de kust was vrij groot en moeilijk, terwijl de afzet van het erts naar de staalproducerende landen van M. en Z.-Amerika en de U.S.A. economisch ondoenlijk was. De meeste hunner beschikten òf over eigen reserves van veel hoogwaardiger erts of konden dat voordeliger uit meer nabij gelegen landen betrekken. Aan een eigen staalindustrie en walserij voor export, zonder enige steun van de binnenlandse markt, kon uiteraard niet worden gedacht (13).

De produktie van goud, omstreeks I89o nog een belangrijk exportprodukt, bedroeg in I96o nog slechts $125 \mathrm{~kg}$ per jaar.

BOUWNIJVERHEID

Hoewel men overtuigd was, dat in de komende jaren op grote schaal tot volkswoningbouw zou moeten worden overgegaan, in het bij- 
zonder in de hoofdstad waar de bevolking snel in omvang toenam en grote complexen krotwoningen dienden te worden opgeruimd, waren op het minimumplan voor dit doel geen fondsen meer beschikbaar. Bovendien werd gevreesd, dat het aantal geschoolde bouwvakarbeiders voorlopig onvoldoende was om een grootscheeps projekt voor volkswoningbouw in de eerstkomende jaren te realiseren.

Op het supplementaire plan werd echter een groot bedrag uitgetrokken om een later op te richten 'Stichting Volkswoningbouw' in staat te stellen onder garantie van de Overheid op de binnenlandse markt leningen in kleine coupures te plaatsen.

\section{ENERGIEVOORZIENING}

Het Brokopondowerk, dat o.m. de bouw van een stuw in de Surinamerivier omvatte, waardoor een meer van $1500 \mathrm{~km}^{2}$ zou ontstaan, en een krachtstation met een vermogen van ${ }_{5} 50.000$ $\mathrm{KW}$, stond zoals gezegd buiten het T.J.P. Aangezien het projekt voor de industriële ontwikkeling van Suriname van eminent belang werd geacht - de electrische-stroomprijs was in Suriname hoog, o.m. in verband met de noodzaak de benodigde steenkool in te voeren - werd het vooronderzoek met plangelden gefinancierd.

Vóór alles moest echter ter plaatse een fundamenteel topografisch-geologisch en hydrologisch onderzoek worden ingesteld naar de technische uitvoerbaarheid van het plan. Voorts moest een gunstig tracé worden gezocht voor de hoofdontsluitingsweg en diende te worden nagegaan waarheen de bewoners van het toekomstige stuwmeergebied zouden kunnen worden verplaatst.

Verder was het zaak na te gaan, welke invloed het projekt zou uitoefenen op de bestaande ecologische en hygiënische toestand van het land. Er moest uiteraard absolute zekerheid bestaan, dat er genoeg stroom zou kunnen worden opgewekt tegen een prijs, welke voldoende laag was om een mogelijkheid te openen voor de vestiging van een aluminiumreductiebedrijf met een jaarproduktie van circa 50.000 ton. Voor de fabricage van I ton metaal was namelijk niet minder dan $21.000-23.000 \mathrm{kWh}$ vereist.

Niet alle opgewekte energie zou voor de aluminiumfabricage mogen worden aangewend, opdat er voldoende resteerde voor de industriële ontwikkeling van Suriname gedurende de komende Io à 20 jaar. Deze stroom zou moeten worden geleverd tegen een prijs die belangrijk lager was dan elders in het Caraïbische gebied om de concurrentiepositie van de Surinaamse industrie te ver- 
sterken. Aan de hand van de resultaten van dit onderzoek zou een exacte calculatie van de kostprijs mogelijk zijn, met welk gegeven aluminiumfabrikanten zouden kunnen worden geinteresseerd. Het was duidelijk, dat met de aanleg van stuwdam en centrale eerst kon worden begonnen indien de oprichting van een aluminiumbedrijf verzekerd was.

Het Brokopondoprojekt kon verder als een multipurpose projekt worden opgevat, omdat het een deel van het Surinaamse achterland ontsloot. De exploitatie van rijke, doch te geïsoleerde bauxietafzettingen zou daardoor mogelijk kunnen worden, terwijl de oprichting van landbouw- en veeteeltondernemingen enigermate werd vergemakkelijkt.

De bosstroken langs de meeroevers, zouden, - zo dacht men indien zij waardevol hout bevatten, in exploitatie kunnen worden genomen, daar de afvoer van het hout via het meer en een vlotgoot bij de stuw, over de Suriname-rivier zou kunnen plaatsgrijpen. Het meer zou voorts voor visserij-doeleinden kunnen worden benut. Ook zou de zoutgrens in de benedenSurinamerivier door de regelmatige afvoer van grote massa's water wellicht worden verschoven, waardoor, met behulp van pompinstallaties, die hun energie aan het Brokopondoprojekt ontleenden, bevloeiing van een vlak deel der oude kustvlakte mogelijk zou worden. Tenslotte kon de Brokopondo-omgeving mettertijd een belangrijke uitbreiding betekenen voor de beperkte recreatie-mogelijkheden van Suriname in het algemeen en van de hoofdstad in het bijzonder.

TERTIAIRE SEKTOR

\section{HET VERKEER}

Om verschillende, in de eerste plaats economische redenen, werd in een verbetering van de verkeerssituatie, vooral in de kuststrook waar het economische leven zich concentreerde, een absolute noodzaak gezien voor de ontwikkeling van Suriname.

Omstreeks I950 viel dit gebied in feite uiteen in vier economisch-geografische landschappen (I4), die slechts op primitieve wijze langs de rivieren en kreken met elkaar in verbinding stonden. Deze landschappen vormden enerzijds landbouwproduktiecentra, anderzijds afzetgebieden voor de in Paramaribo vervaardigde of geïmporteerde industriële verbruiksgoederen.

Door het wegverkeer tussen deze centra te verbeteren zouden de voor binnenlands verbruik of export bestemde, veelal aan 
bederf onderhevig zijnde landbouw- en visserijprodukten snel en in groter kwantum in de hoofdstad ter markt kunnen worden gebracht door de producenten zelf of, als dit in verband met de beperkte hoeveelheid ondoelmatig mocht zijn, met behulp van een zo kort mogelijke keten van tussenhandelaren.

De bouw van een modern geoutilleerde centrale markt, met een groot oppervlak aan koelruimte voor het bewaren van bederfelijke produkten als vlees, vis, fruit en groenten werd in verband hiermede noodzakelijk geacht.

De industriële verbruiksgoederen, niet tot de categorie der massaprodukten behorende, welke laatste goedkoper over water konden worden vervoerd, zouden daardoor ook niet meer tegen onevenredig hoge prijzen op het platteland behoeven te worden aangeboden.

Het reële inkomen van de boer zou daardoor stijgen waardoor de divergentie tussen stedelijk en landelijk welvaartsniveau enigermate werd verkleind.

De wegen die in het kader van het plan werden ontworpen ontsloten vanzelfsprekend tegelijkertijd de landbouwprojekten die in de maagdelijke gebieden tussen de centra waren geprojekteerd.

Nochtans bleef de binnen- en kustscheepvaart welke goeddeels behartigd werd door de Scheepvaart Mij. 'Suriname', een overheidsonderneming, van belang zodat aan de verbetering van de waterwegen en aan de uitbreiding van de vloot met coasters, in het bijzonder om de verbindingen te kunnen onderhouden met de landen en eilanden van het Caraíbische gebied, eveneens aandacht moest worden geschonken.

De volstrekt onvoldoende outillage van de haven van Paramaribo was een der oorzaken van de hoge kosten waarmede laden en lossen gepaard gingen, in verband waarmede een aanmerkelijke verbetering van de haveninrichting met inbegrip van een uitbreiding van de opslagaccommodatie met het oog op de in de naaste toekomst te verwachten toeneming van de inkomende en uitgaande goederenstroom, niet achterwege kon blijven.

Ook was verbetering van het vliegveld uitermate urgent, wilde Suriname bij het internationale vliegverkeer ingeschakeld blijven, terwijl de oprichting van een bescheiden binnenlandse luchtvaartmaatschappij voor een snelle verbinding tussen de volkrijke centra van het platteland en de hoofdstad, ook uit bestuurlijk oogpunt gewenst was. 
Tenslotte was het van belang om het landelijk telefoonnet te verbeteren en uit te breiden.

Voor een uitbouw tot een doeltreffend functionerend verkeerswezen zou een aanzienlijk groter bedrag nodig zijn geweest dan thans ten laste van het plan werd gebracht. Vooral met het oog op het inflatiegevaar, moest echter genoegen worden genomen met een beperkt maar zorgvuldig samengesteld verkeersprogramma.

Met een technische voorbereiding van de civiele werken werd een 'Bouwbureau' belast, dat evenmin als het B.L.O. een onderdeel was van het Planbureau, maar een zelfstandig directoraat van het Departement van Openbare Werken en Verkeer. De uitvoering der werken zou principieel bij openbare aanbesteding plaats hebben maar aangezien de grote kern van vaste arbeiders, waarover het departement beschikte geregeld aan het werk moest worden gehouden, zou in de komende jaren herhaaldelijk van dit principe worden afgeweken. Vooral het verkeersprojekt had zich bij uitstek geleend om door een gespecialiseerd particulier Nederlands concern te worden uitgevoerd.

DE HANDEL

In het kader van het plan zou in directe zin weinig aan de handel kunnen worden gedaan.

Het havenprojekt voorzag ook in een uitbreiding van de opslagaccommodatie, maar niet in voldoende mate. Verdere uitbreiding daarvan lag weliswaar op de weg van de particuliere handel, maar zoals ook ten aanzien van de padi-drogerijen en opslagplaatsen werd gehandeld, zou de overheid ook hier hulp moeten bieden door de oprichting van een veembedrijf mogelijk te maken. Een dergelijk bedrijf zou de handel nog het voordeel bieden, dat op de opgeslagen goederen celen konden worden uitgereikt die bij de banken verhandelbaar waren.

TOERISME

Van een werkelijk toerisme was geen sprake en derhalve bestond er voorlopig geen aanleiding om dit te stimuleren. De geringe recreatiemogelijkheden en de slechte communicatiemiddelen rechtvaardigden deze beslissing.

\section{SOCIALE SECTOR}

Aangezien het niet mogelijk was een ontwikkelingsplan uit te voeren zonder grote aandacht te besteden aan het onderwijs, de medisch-hygiënische verzorging en andere sociale aspecten, 
werden op het minimum- en het supplementaire plan voor deze doeleinden grote bedragen uitgetrokken.

Gezien de geaccumuleerde achterstand in deze sector, waren deze bijdragen wel redelijk, maar aan de vergaande financieelmonetaire en economische consequenties daarvan mocht toch niet worden voorbij gezien, omdat nieuwe hospitalen, scholen, etc. in de komende jaren op de landsbegroting immers een verhoogd bedrag voor personele, materiële en onderhoudskosten, vereisten terwijl nieuwe verplichtingen voortvloeiden uit het feit, dat door de verbetering van de hygiënische toestanden de bevolking in versneld tempo toenam, welk accres in de laatste jaren op 3.5 à $4 \%$ per jaar werd geraamd.

INDIENING VAN HET TIENJARENPLAN

Medio I952 bood het Planbureau de Surinaamse Regering een nota aan, waarin de grondslagen van een Tienjarenplan (I5) werden uiteengezet, een geschrift waarin het monetair-financiële en economische aspect zeer uitvoerig, de projekten met de daarmede samenhangende vraagstukken zeer beknopt werden behandeld.

Uit onderhandse besprekingen kwam spoedig vast te staan, dat het bedrag hetwelk voor de landbouw was uitgetrokken te gering werd geacht, temeer omdat men het z.g. Wageningenprojekt als een Nederlandse aangelegenheid opvatte, waarvan de Surinaamse economie weinig profijt trok en dat derhalve niet in het plan thuis hoorde. Het had bovendien steeds in de bedoeling gelegen de financiering van dit projekt op andere wijze te regelen. Voorts werd de luchtkartering van de Zuidelijke helft van het land urgent geacht, evenals de aanleg van een nieuwe luchthaven, de oprichting van een binnenlandse luchtvaartmaatschappij en het tot stand komen van een doorgaande autoweg, die het uiterste Oosten met het uiterste Westen van het land verbond.

Ook diende meer aandacht te worden gegeven aan het gewone en technische onderwijs, de verbetering van het Overheidsapparaat, de werkgelegenheid mede ten bate van de boslandbevolking die in de primitieve boskap- en ladangbouw een schamel bestaan vond, en aan het tijdelijk aantrekken van deskundigen met langjarige tropenervaring in de vorm van 'technische bijstand'.

Bovengenoemde bezwaren tegen het planontwerp, alsmede de 
gegevens van het voortgezette fundamentele onderzoek welke ter beschikking waren gekomen, maakten een herziening van het schema noodzakelijk. Hierbij diende niet te worden uitgegaan van hetgeen binnen het raam der beschikbare middelen zou kunnen worden gerealiseerd, maar van wat voor een permanente verbetering van 's Lands economie noodzakelijk werd geacht waardoor een supplementair plan overbodig werd. Het nieuwe plan zou daarom meer het karakter van een intentieplan dragen en daardoor ook flexibeler worden.

Binnen de bedragen die voor de verschillende sektoren en deelplannen zouden worden uitgetrokken, konden derhalve, in overeenstemming met de omstandigheden, veranderingen worden aangebracht. Deze min of meer incidentele wijzigingen, welke niet onwaarschijnlijk soms onder politieke druk zouden moeten worden aangebracht, bemoeilijkten uiteraard het handhaven van de geprojekteerde gecoördineerde maatregelen op lange termijn, welke het bereiken van een bepaalde situatie op economisch en financieel-monetair gebied aan het einde van de planperiode ten doel hadden.

Een ander belangrijk verschil met het oorspronkelijke plan was, dat onder druk van Hindostaanse zijde, ruim driemaal meer bouwland zou moeten worden aangewonnen, niet in de districten, maar juist in de omgeving van Paramaribo. De daarmee gepaard gaande veel grotere uitgaven konden, naar men aannam, zonder bezwaar beperkt worden door de gronden niet bouwrijp op te leveren en de ontginning etc. over te laten aan de toekomstige grondbezitters.

Het nieuwe plan vereiste een investering van Sf. $127 \mathrm{mln}$, exclusief dus het Wageningen-projekt, hoewel dit zoals in de aanvang gezegd, een der hoekstenen daarvan vormde, de beide experimentele projekten Lelydorp en Slootwijk, welke gefinancierd zouden worden door een nieuw opgerichte 'Stichting experimentele bedrijven', die de beschikking kreeg over een deel der overgebleven fondsen van het 'Welvaartsfonds' in liquidatie, en het verdere Brokopondo-onderzoek dat uit andere hoofde zou worden gefinancierd.

In oktober I954 werd een herzien plan aan de Regering aangeboden en na goedkeuring door de Staten aan de Nederlandse Regering toegezonden met het verzoek, in om de uitvoering daarvan op nader overeen te komen voorwaarden te participeren. (r6)

De uitvoering van het Brokopondo- en van het Wageningen- 
projekt, gelijktijdig met het T.J.P. maar nochtans onafhankelijk daarvan, vereiste echter een voortdurend en nauw overleg tussen de directies van deze ondernemingen, wilden spanningen op financieel-monetair en op het gebied der arbeidsvoorziening uitblijven.

Tijdens het overleg tussen beide regeringen bleek, dat Nederland tegenover het herziene plan zeer welwillend stond, zodat t.a.v. de financiering en de wijze waarop de gelden beschikbaar zouden worden gesteld, spoedig overeenstemming werd bereikt. De voorgestelde financiering kwam kortweg hierop neer, dat Nederland één derde van het benodigde bedrag schonk en één derde in de vorm van langdurige leningen ter beschikking stelde, indien Suriname zelf het resterende derde deel of globaal Sf.4 mln 's jaars, op zich zou nemen.

\section{DE RESULTATEN VAN HET TIENJARENPLAN}

Hoewel het T.J.P. officieel op I januari 1955 in werking trad, dateren de pogingen tot verhoging van het welvaartsniveau in Suriname reeds uit 1948 , het jaar waarin het Welvaartsfonds werd opgericht.

Toch zou het niet billijk zijn thans reeds te verwachten, dat de doelstellingen duidelijk naderbij waren gekomen, maar wel zouden er aanwijzingen kunnen zijn, dat men zich op de goede weg bevond.

Hoewel aan de hand van de nog steeds zeer onvolledige en daardoor uiterst moeilijk te interpreteren statistische gegevens slechts een vaag beeld kan worden verkregen van de ontwikkeling van 's Lands economie gedurende de laatste jaren, schijnen de volgende conclusies toch wel gerechtvaardigd.

Van een verhoging van het reëel inkomen per hoofd van de geregistreerde bevolking viel nog niet veel te bespeuren daar dit in de jaren I954 t/m I958 tegen prijzen van I954, respectievelijk Sf.430, Sf.43I, Sf.4I9, Sf.433 en Sf.42I bedroeg. Exacte gegevens betreffende de ontwikkeling van het reëel inkomen in de laatste jaren zijn niet beschikbaar maar uit het feit, dat de jaarlijkse stijging van het bruto nationaal produkt tegen factorkosten in in de eerste periode gemiddeld $6,5 \%$ bedroeg tegen gemiddeld $4,3 \%$ in de jaren r 960 en ' $6 \mathrm{r}$ ( $\mathrm{I} 8$ ) terwijl het jaarlijks bevolkingsaccres eerder toe- dan afnam en het binnenlands prijspeil in de laatste jaren verder steeg, zou kunnen worden afgeleid, dat de econo- 
mische groei van Suriname tot dusver te wensen heeft overgelaten.

Teleurstellend was vooral de ontwikkeling van de bevolkingslandbouw. De landbouwprodukten hadden in de jaren I957/6r een brutowaarde van gemiddeld Sf. Io, $2 \mathrm{mln}$ p. j. tegen naar schatting Sf. 9,0 mln in 1954 of met inbegrip van de voortbrengselen van de veehouderij Sf. I4,9 mln tegen Sf. I2,7 mln.

De gemiddelde produktie van de landbouw en veeteeltbedrijven had in 1954 een brutowaarde van Sf. 800 tegen gemiddeld Sf. 940 in de periode r $957 / 6 \mathrm{r}$ en Sf. 840 in de jaren r96o/6r.

Aangezien $19,7 \%$ van de bedrijven $\mathrm{I}$ ha of kleiner was, $27,4 \%$ een omvang had van I-2 en $I_{5}, 8 \%$ van $2-3$ ha (2I) en de brutoopbrengst per geoogste hectare in het tijdvak I957/6r Sf. 442 bedroeg, zal het duidelijk zijn, dat de economische positie van de landbouwers nog weinig verbeterde, temeer daar ook voor hen de kosten van levensonderhoud sinds I954 niet onaanzienlijk waren gestegen.

De discrepantie tussen stedelijk en landelijk inkomen bleef dan ook gehandhaafd.

Door voor een aantal voorname produkten minimumprijzen vast te stellen, wat in feite neerkwam op het verstrekken van subsidies, trachtte de Overheid het boereninkomen op een enigszins aanvaardbaar niveau te stabiliseren.

De in 1955 door de Overheid opgerichte Landbouw Produkten Centrale welk orgaan verplicht was tot aankoop der produkten over te gaan indien de minimumprijs niet werd gehaald, leed in de jaren I956/6o een verlies van Sf. 341.00o op een omzet van Sf. I,37 mln (22).

Ten aanzien van de plantages kan worden opgemerkt, dat de brutowaarde van hun produktie in de jaren 1957/6r gemiddeld Sf. 7,3 mln beliep.

Het gemiddelde aandeel hierin van de twee suikerondernemingen, waarvan 'Mariënburg' van de Ned. Handel Mij. verreweg de belangrijkste is - en van het Wageningenprojekt, bedroeg respectievelijk Sf. 3,4 en Sf. 2,7 mln.

De landbouwexport die in I950 een waarde vertegenwoordigde van Sf. $2.7 \mathrm{mln}$ steeg tot gemiddeld Sf. $6,88 \mathrm{mln}$ in $1958 / 60$. Het aandeel van de ondernemingen hierin nam toe van $40 \%$ tot bijna $83 \%$ in 1960 , waarvan echter circa $5,5 \%$ voor rekening kwam van 'Mariënburg' en $39 \%$ van 'Wageningen'. Laatstgenoemd bedrijf kwam tot dusverre nog niet: tot een lonende ex- 
ploitatie. De verliezen bedroegen in I959, I96o en I96r respectievelijk Sf. I,74, Sf. I,36 en Sf. 0,37 mln exclusief de bedragen van Sf. I,25, Sf. I,I7 en Sf. I,I6 mln aan rente en aflossing van leningen, waarvoor Nederland zich garant had gesteld en die derhalve ten laste kwamen van de Nederlandse schatkist. In feite werd dus een deel van de Surinaamse export door Nederland gesubsidieerd.

De geringe economische betekenis van de overige plantages wier bestaan vnl. afhing van de citrus- en koffiecultuur, kan uit bovenstaande worden afgeleid. Te hunnen behoeve kwam in I956 met behulp van T.J.P.-fondsen een citrusexportgarantieregeling tot stand waarbij per exportkrat sinaasappelen of grapefruit een minimumprijs werd gegarandeerd, waardoor zij in staat waren hun aanplant door bepaalde cultuurmaatregelen te saneren en de kwaliteit van het fruit te verbeteren. Inderdaad is hierdoor het exportvolume van citrusfruit toegenomen maar helaas met toenemende verliezen welke ten laste kwamen van de garantieregeling, die van $1956 \mathrm{t} / \mathrm{m}$ I96o reeds een totaalverlies te betreuren had van Sf. $0,56 \mathrm{mln}$ op een omzet van 708.132 kratten.

De grote moeilijkheden die in het laatste jaar bij de afzet van de Surinaamse Liberia koffie werden ondervonden waren voor de Overheid aanleiding aan de nieuw opgerichte Suriname-Koffieproducenten Centrale steun te verlenen in de vorm van een voorschot op de voorraden en op de door bedoelde organisatie verkochte en geëxporteerde koffie.

Verder besloot de Overheid op verzoek van de ondernemingen bij te dragen in de kosten van de conversie der koffieaanplantingen in citrus of een ander gewas, niettegenstaande een in 1935 uitgevaardigde gelijksoortige maatregel later, toen de koffieprijzen tijdelijk zeer hoog waren, door de planters scherp werd bekritiseerd (23). Welke financiële consequenties dit voor de schatkist zal hebben valt thans nog niet te zeggen, maar enig pessimisme is zeker op zijn plaats. Echter mag niet over het hoofd worden gezien, dat de landbouwondernemingen nog aan circa 2300 arbeiders geregeld werk verschaffen, waarvan 750 met hun gezinnen op het Wageningenprojekt werkzaam waren.

Associatie met de E.E.G. zal de afzet van de agrarische exportprodukten kunnen vergemakkelijken indien kan worden geconcurreerd met de voormalige overzeese gebieden der lidlanden, die evenzo hout, koffie, cacao, bananen en citrus uitvoeren en met deze landen zelf met betrekking tot rijst en citrus. 
In de veeteeltsektor werd een aanzienlijke stijging van de melkproduktie verkregen door uitbreiding van de veestapel, betere verpleging van het vee en door de verplichting van de sinds I96I werkende melkcentrale om alle aangeboden melk tegen een redelijke prijs af te nemen. Nochtans nam de import van melkprodukten gestadig toe hetgeen enerzijds moest worden toegeschreven aan de toegenomen consumptie (door de in uitvoering zijnde Tienjaren en Brokopondoplannen kwamen relatief grote geldbedragen onder de stadsbevolking waardoor de koopkracht aanzienlijk steeg) waarin de binnenlandse produktie nog niet kon voorzien, anderzijds aan de ongunstige prijsverhouding tussen de inheemse melk en de melk bereid uit geïmporteerde conserven. Deze ongunstige situatie werd in de hand gewerkt door de hoge inkoopprijs die de Centrale voor de grondstof moest betalen.

Ook de vleesproduktie nam in onvoldoende mate toe, hetgeen een vergrote invoer van vleesconserven ten gevolge had.

$\mathrm{Bij}$ de visserij was het eigenaardig, dat niettegenstaande de visaanvoer sinds 1952 verdubbelde, de import van conserven bleef stijgen. De oorzaak hiervan kan zeker niet uitsluitend worden gezocht in een toegenomen consumptie, maar prijsverhoudingen en het feit dat bepaalde conserven nog niet in voldoende mate lokaal kunnen worden geproduceerd, zullen mede een rol spelen. Aangezien in dit laatste wel verandering kan komen blijft verhoging der produktie noodzakelijk, wat echter geen eenvoudige zaak is.

De rentabiliteit van een zeevisserij, die zich uitsluitend op de vangst van vis toelegt schijnt in Suriname marginaal te zijn, terwijl een combinatie met de veel lucratiever garnalenvisserij om technische redenen niet wel mogelijk is.

Hoewel de produktie van de binnenvisserij belangrijk kan worden verhoogd, vooral nu de geïmporteerde vissoort Tilapia mosambica in alle opzichten gunstige perpectieven opent en ook het Brokopondostuwmeer dienaangaande wellicht grote mogelijkheden biedt, zal import voorshands noodzakelijk blijven, ook al omdat de invloed der seizoenen op de aanvoer zowel van zee- als zoetwatervis groot is en er voorlopig steeds schaarsteperioden moeten worden overbrugd.

Een spectaculair succes werd behaald met de garnalenvisserij ver buitengaats. $\mathrm{Na}$ een op directe resultaten gericht onderzoek, kon de geheel verlopen export sterk worden opgevoerd en had deze in I960 reeds een waarde van Sf. o,65 mln. Schier nog 
belangrijker was, dat thans een particuliere maatschappij, welke over een eigen trawlervloot en een garnalenverwerkingsfabriek beschikt, de garnalenvisserij in het groot beoefent.

De teleurstellende resultaten, in het bijzonder van de kleinlandbouw, waren in de eerste plaats toe te schrijven aan de dalende prijzen der agrarische grondstoffen op de wereldmarkt. De indexcijfers van rijst, koffie en cacao $(\mathrm{r} 953=\mathrm{IOo})$ waren in I961 59, 63 en 63, voorts aan het bijzonder ongunstige verloop van de regenval in de laatste 5 jaren. Zware oogstdervingen waren daarvan het gevolg, aangezien nog steeds op $70 \%$ der bouwvelden de waterhuishouding onbevredigend is. Hoewel reeds vóór de tweede oorlog dit vraagstuk aan de orde werd gesteld, werd eerst in 1958 een aanvang gemaakt met een intensief onderzoek naar de mogelijkheid om in de bestaande situatie verbetering te brengen.

Een andere oorzaak was gelegen in de betrekkelijk geringe vorderingen van het landbouwkundig onderzoek (behoudens de belangrijke bodemkartering) en de daarop steunende landbouwvoorlichting, hetgeen tot uiting kwam in het nog geringe gebruik van meststoffen, ziektebestrijdingsmiddelen en zaaizaad van rijstrassen, die beter dan de huidige, aan de omstandigheden waaronder de gemiddelde landbouwer de cultuur moet uitoefenen, zijn aangepast.

Niet onvermeld kan blijven, dat door verschillende oorzaken het Slootwijkprojekt volledig, en het Lelydorpplan grotendeels mislukten. Het laatste experiment gaf tenminste nog een aanwijzing, dat op bepaalde vlakke gronden van het Lelydorpareaal, gezinsbedrijven van 4 à 6 ha, die de teelt van een overjarig gewas combineerden met een intensieve veehouderij, een economische propositie vormden. Nochtans toonde de bevolking voor deze mogelijkheid weinig belangstelling.

Voorts bleek het een grote fout te zijn geweest om de nieuw gewonnen of gesaneerde gronden niet bouwrijp op te leveren waardoor zij mede door de onvoldoende credietvoorziening, slechts zeer langzaam in cultuur werden gebracht.

Aangezien de Volkscredietbank slechts leningen verstrekte aan credietbevoegden, vielen nog niets bezittende nochtans vakbekwame jonge boeren van onbesproken gedrag, buiten de hulp. Door de oprichting in 1957 van een Landbouw Kredietfonds met behulp van T.J.P. fondsen, konden de kolonisten in de nieuwe polders aan bouw- en bedrijfscrediet worden geholpen, 
waarvan de omvang, aanwending en aflossingstermijnen meestal door daartoe opgeleid landbouwpersoneel werden vastgesteld en gecontroleerd.

De kolonisten konden echter eerst na twee jaar een zakelijk recht op grond verwerven indien zij daadwerkelijk van hun bekwaamheid, ijver en gemeenschapszin blijk hadden gegeven. Deze regeling opende voor de nieuw gecreëerde dienst 'Projektbeheer' de mogelijkheid om hen, die niet aan de gestelde eisen voldeden of zich niet hielden aan de voorschriften betreffende bedrijfsinrichting en bedrijfsvoering, te verwijderen.

Of deze rigoreuze maar zeker effectieve werkwijze, zal leiden tot een zelfstandig denkende en handelende boerenstand en of de gunstige gang van zaken zal worden gecontinueerd als onverhoopt het toezicht minder intensief wordt, zal de toekomst moeten uitwijzen.

De ervaring elders in de tropen leerde, dat indien de vaak niet begrepen overheidsbemoeienis, om de een of andere reden moet worden gestaakt, de landbouwer snel op zijn traditionele werkwijze terugvalt. Het zou wellicht beter zijn geweest, als de Overheid de nieuwe polders als waterschappen had georganiseerd met een met gezag bekleed bestuur uit en door de ingelanden gekozen. Dwingende maatregelen van een eigen bestuur roepen minder spanningen op dan ingrijpen van de Overheid gemeenlijk doet.

Indien de polderbewoners bovendien tot dezelfde rasgroep hadden behoord, zou er voldoende gemeenschapszin zijn geweest, om de aanwending van periodiek overtollige gezinsarbeid bij aanleg en onderhoud van werken van algemeen nut mogelijk te maken. Dit zou niet onbelangrijke financiële voordelen met zich hebben mee gebracht. Thans wordt echter een politiek gevolgd, welke beoogt de samenstelling der bevolking in de nieuwe polders te doen overeenkomen met die van de betrokken streek.

De houtbewerkende industrie en houtexport hadden de laatste jaren ernstige tegenslagen te incasseren. Hoewel de houtproduktie, dank zij de activiteiten van het uitstekend functionerende Boswezen, dat einde I96r 250.000 ha bos had geïnventariseerd waarvan 83000 ha (I2000 ha zwampbos) ontsloten, regelmatig steeg, daalde de uitvoer van Basralocus, een van de weinige Surinaamse houtsoorten die in Europa speciaal voor waterbouwkundige werken geliefd is, mogelijk door een toegenomen concurrentie van Azobé uit West-Afrika en van Greenheart uit Demerara. 
De sinds 1958 moeilijk op gang gekomen export van spaanplaten naar de U.S.A. en Puerto Rico kwam door een even plotselinge als zware verhoging der invoerrechten vrijwel tot stilstand en noopte tot het zoeken naar andere afzetgebieden, wat gelukkig succes boekte. Deze uitvoer steeg van Sf. 0,035 $\mathrm{mln}$ in I 958 tot Sf. I,54 mln in I96r, waardoor de totale waarde van de houtexport welke van Sf. $5,87 \mathrm{mln}$ in $1956 / 59$ was gedaald tot Sf. $5,64 \mathrm{mln}$ in I96o voornamelijk als uitvloeisel van de moeilijkheden welke de export van triplex naar Cuba ondervond, weer kon stijgen tot Sf. $6,28 \mathrm{mln}$.

Het streven van de Surinaamse Hout Mij. om door de sterk uitgebreide zagerij-schaverij instede van gezaagd hout hoogwaardiger produkten te doen leveren als vloeren, deuren, ramen, pre-fabhuizen etc. mede voor export, boekte succes.

Een proefneming om het veel voorkomende Mierenhout te doen benutten voor mijnstutten in het Roergebied, mislukte als gevolg van de zwaar drukkende vervoerskosten. Gelukkig dat deze houtsoort thans lokaal kan worden aangewend om de spaanplaten die voornamelijk vervaardigd worden uit de baboenhoutafval van de triplexfabriek, door bijmenging meerdere sterkte te geven.

Bijzonder grote teleurstelling veroorzaakte het onlangs genomen besluit van de Koninklijke Papierfabrieken van Gelder $\mathrm{Zn}$. om de door haar bekostigde proefnemingen met Pinus caribaea, welke in 1952 onder leiding van het Boswezen werden aangevangen, te beëindigen, hoewel de resultaten hoopgevend waren. Het lag eertijds in de bedoeling van genoemd concern om een produktiebos van circa 40.000 ha (later tot de helft gereduceerd) aan te leggen, dat had kunnen bijdragen in de grondstofvoorziening van haar fabrieken in Nederland. Waarschijnlijk rest thans Suriname geen andere mogelijkheid, dan de aanleg van naaldhoutbossen op eigen kosten in overweging te nemen om deze, zoals enkele andere landen dat deden, later aan de pulpindustrie aan te bieden, waarbij dan kan worden bedongen, dat ter plaatse een pulp- c.q. papierfabriek wordt opgericht. Bosaanleg vergt echter een enorm kapitaal dat eerst na $I_{5}$ à 20 jaar enige baten begint af te werpen.

Het aandeel van de bauxiet in de totale uitvoerwaarde bedroeg in I96r circa $83 \%$ tegen $82 \%$ in 1950 , terwijl de gemiddelde landsinkomsten in de periode $\mathrm{I} 954 \mathrm{t} / \mathrm{m}$ 6r waarschijnlijk voor rond $37 \%$ afhankelijk waren van de bauxietwinning tegen $33 \%$ in 1950 .

Van een verbreding van de economische basis van het land 
was derhalve nog weinig sprake. Veeleer het tegendeel, daar het procentuele aandeel van de landbouw, veeteelt en visserij in de totale uitvoerwaarde daalde van gemiddeld $10 \%$ in $1958 / 60$ tot $8 \%$ in r $196 \mathrm{r}$. Aangezien de invoer van agrarische produkten in genoemde jaren met $16,5 \%$ toenam, steeg het negatieve saldo op de handelsbalans van agrarische produkten van gemiddeld Sf. 4,3 tot Sf. 8,3 mln.

Het procentuele aandeel van de bosprodukten en halffabrikaten daarvan in de totale uitvoerwaarde dat in de jaren $1957 / 58$ ruim $10 \%$ bedroeg, daalde in $1960 / 6$ I tot ongeveer $9 \%$.

Het percentage van de totale invoerwaarde dat gedekt werd door de uitvoer, daalde van $106 \%$ in 1954 tot $77 \%$ in 1961 .

Wordt in aanmerking genomen, dat van I957 het prijspeil waarop de bauxiet met de Suriname Aluminum Company werd verrekend gestadig steeg, dan was genoemd dekkingspercentage nog geflatteerd te noemen.

De invoerwaarde van gebruiksgoederen, inclusief voedingsmiddelen en dranken steeg in de periode $1954-1961$ met $50 \%$. Deze ongunstige situatie werd weerspiegeld in het toenemende deficit op de lopende rekening van de betalingsbalans, dat in r958 Sf. I4,o mln bedroeg tegen Sf. $36,3 \mathrm{mln}$ in I96o en Sf. 44,8 mln in 1961 .

In deze tekorten kon slechts in onvoldoende mate worden voorzien door invoer van buitenlands kapitaal o.m. in de vorm van schenkingen, leningen en particuliere investeringen, hetgeen zich manifesteerde in een vermindering van de goud- en deviezenvoorraad, waardoor het dekkingspercentage van de Surinaamse munteenheid van $85 \%$ in I959 tot $54 \%$ medio I 962 daalde.

De steeds zwakker wordende positie van de Surinaamse gulden deed de vlucht in onroerend goed toenemen. De vele nieuwe gebouwen en woonwijken in de hoofdstad, de vele personenauto's en bromfietsen wier aantal van I954 tot I96I resp. steeg van I 430 tot 4903 en van o tot Io729, gaven de indruk van welvaart, maar in wezen kwamen er in de fundamentele tekortkomingen van de economie geen veranderingen ten goede.

Van de zo vurig begeerde economische en financiële zelfstandigheid kwam nog weinig terecht.

De uitgaven van het land stegen in de laatste jaren sneller dan de inkomsten zodat er evenals voorheen begrotingstekorten waren te betreuren. Hier dient te worden vermeld, dat de uit- 
breiding welke aan het ambtenarencorps werd gegeven in geen enkele verhouding stond tot de toeneming van de Overheidstaak en bovendien het werkloosheidsvraagstuk verdoezelde. Het aantal ambtenaren klom van ${ }_{5} 530$ in 1938 tot $\mathrm{Ir} .963$ in $\mathrm{r} 96 \mathrm{r}$.

In dit jaar werd $53 \%$ der uitgaven van de gewone dienst aan salarissen besteed, een bedrag dat $20 \%$ uitmaakte van het nationale inkomen tegen factorkosten.

In 1957 bleek een verhoging der invoerrechten op een aantal belangrijke verbruiksgoederen, dadelijk te resulteren in een stijging van de kosten van levensonderhoud met $4 \%$, zodat deze maatregel ter vermeerdering van 's Landsinkomsten, gedeeltelijk weer ongedaan moest worden gemaakt.

In het bijzonder stegen de uitgaven van de buitengewone dienst, niet alleen als gevolg van de in de laatste paar jaar geforceerde uitvoering van het T.J.P. - tegenover de uitgaven stonden immers de bijdragen van Nederland à fonds perdu en als lening - maar vooral ook van de financiële consequenties van enkele buiten het plan vallende kostbare, niet direkt produktiebevorderende projekten. B.v. het ter versnelling van de mijnbouwkundige exploratie ingestelde aerografisch onderzoek met inbegrip van de daarbij behorende aanleg van air-strips in het diepe binnenland en het plan tot ontwikkeling van de streek rond het Brokopondokrachtwerk. Bovendien werd een kostbaar bureau opgericht, dat als vertegenwoordiger van de Regering toezicht moest uitoefenen op de uitvoering van het Brokopondoprojekt en daarmede samenhangende werkzaamheden en voorts de opdracht ontving een onderzoek in te stellen naar de uitbreidingsmogelijkheden van het waterkrachtpotentieel van het ganse land.

De begrotingstekorten dwongen de Overheid in toenemende mate een beroep te doen op de binnen- en buitenlandse kapitaalmarkt. De nationale schuld steeg van Sf. 2,94 mln in 1954 tot Sf. 48,23 mln in I96I, waarvan respectievelijk Sf. 2,32 en Sf. 7,49 mln op rekening kwam van binnenlandse leningen.

Van de T.J.P. gelden, welke in de periode I954/196I werden verwerkt kwam slechts circa $38 \%$ ten goede aan direct produktiebevorderende projekten, waartoe eveneens het wetenschappelijk onderzoek werd gerekend (circa I5\% der uitgaven); aan de verkeerssektor $39 \%$ en de rest aan de sociale sektor met inbegrip van de uitgaven t.b.v. algemene voorzieningen, openbare nutsbedrijven, de verbetering van het Overheidsapparaat en het 'beheer' van het T.J.P. 
In de verkeerssektor werden in de laatste jaren vele wegen aangelegd en gesaneerd, rivierovergangen verbeterd en kwam o.a. het internationale vliegveld met accommodatie gereed.

In de sociale sektor werd het nodige verricht om de achterstand, in het bijzonder op het platteland, in te halen. Moderne ziekenhuizen, ambtenarenwoningen, scholen, gemeenschapshuizen, sportvelden kwamen aldaar tot stand, benevens werd de water- en lichtvoorziening verbeterd en het telefoonnet uitgebreid. In de stad werd o.m. de primitieve riolering verbeterd, die vooral in de volkswijken de gezondheidstoestand bedreigde en werd de volkswoningbouw gestimuleerd.

In de afgelopen jaren kon het accent helaas niet in meerdere mate worden gelegd op de produktie-bevorderende projekten omdat in het bijzonder de landbouwprojekten, zeer veel onderzoek vergden alvorens tot uitvoering daarvan kon worden overgegaan. Dit onderzoek had echter belangrijk kunnen worden versneld indien het Bureau Landelijke Opbouw zich uitsluitend had beziggehouden met de streekplanning en de uitwerking van de projekten, die slechts een onderdeel vormen van het streekplan, had opgedragen aan een deskundige particuliere instantie.

Om toch een aanvang te maken met het T.J.P. zocht de Regering in de beginne haar heil in de aanleg van wegen, de bouw van bestuurskantoren en andere werken in de verkeersen sociale sektoren.

Het percentage van de sinds 1956 met behulp van aanzienlijke bankcredieten sterk uitgedijde import, dat door de deviezenvoorraad werd gedekt, daalde van 46 tot niet minder dan $30 \%$ in r96r. In de periode $1956 \mathrm{t} / \mathrm{m}$ I96r zette het bankcrediet met $65 \%$ uit. De totale geldhoeveelheid steeg in de periode I955/ I96I met $70 \%$

Uit bovenstaande zal het duidelijk zijn, dat de financiële en monetaire stabiliteit van het land omstreeks I96o ernstige zorgen baarde.

Inflatoire tendenzen, geaccentueerd door een in het laatste jaar verminderde spaarzin en de onvoldoende binnenlandse produktie van verbruiksgoederen alsmede enkele voorname voedingsmiddelen, deden de kosten van levensonderhoud stijgen. Volgens de indexcijfers stegen de totale kosten van levensonderhoud van gezinnen te Paramaribo met een weekinkomen van Sf. 20 tot Sf. 70, van 102 in I954 tot II9 in I96I (3e kw. I953 $=\mathrm{roo})$. De prijzen van de goederen van zuiver Surinaamse oor- 
sprong stegen echter van 103 tot I30, die van inheemse voedingsstoffen zelfs van I03 tot I44. Vooral stegen de detailprijzen van aard- en peulvruchten, groenten, meelbananen en vlees, maar ook die van rijst, daar in samenhang met het streven van de Regering om het inkomen van de rijstproducenten te verbeteren en de export te stimuleren, de verbroken relatie tussen binnenen buitenlandse markt weer werd hersteld.

In verband met de onvoldoende produktie en mogelijk ook met het tijdelijk gestegen stedelijk inkomen enerzijds en het demonstratieeffect anderzijds nam in de periode I954/I96I het importvolume van melk en zuivelprodukten, vlees en visconserven, voorts van aardappelen, peulvruchten en tarwemeel respectievelijk toe met globaal $4 \mathrm{I}, 6 ; \mathrm{I0}, 6 ; \mathrm{I} 2,8 ; 43,6 ; 40$ en $37 \%$.

De belangstelling van buitenlandse particuliere zijde voor investeringen in landbouw en industriële ondernemingen bleef gering niettegenstaande de overheid een regeling trof "houdende fiscale maatregelen ter bevordering van particuliere investeringen," en de vele hoopgevende uitspraken van bezoekende missies en Amerikaanse 'investmentbrokers'.

In de periode I954/1958 bedroegen de bruto-investeringen Sf. $87,57 \mathrm{mln}$, netto Sf. $44,74 \mathrm{mln}$ waarvan respectievelijk 33 , 26 , 16 en $\mathrm{II} \%$ door bauxiet, cultuur, handels- en industriële ondernemingen. Van het bedrag der bruto-investeringen van de cultuurondernemingen ad Sf. $17,5 \mathrm{mln}$ (netto Sf. II,5 mln) kwam $74 \%$ voor rekening van de S.M.L. (90\% van de netto-investering). Bedenkt men, dat de bestaande ondernemingen w.o. die van de Ned. Handel Mij. in het resterende bedrag nog een groot aandeel hadden, dan zal het duidelijk zijn, dat de interesse voor de landbouw van nieuwe investeerders gering was.

In de industriële sektor werdt bruto Sf. 9,8I mln geïnvesteerd (netto Sf. 5,6r mln). In de betrokken periode waren de investeringen van de Suriname Hout Mij. in de uitbreiding en modernisering van haar zagerij, schaverij en opslagplaats, benevens in de oprichting van een kostbare spaanplatenfabriek aanzienlijk, evenzo van de Ned. Handel Mij. in een nieuwe alcoholfabriek, terwijl een zeer moderne bierbrouwerij het levenslicht zag. Andere investeerders namen dus relatief slechts een klein bedrag voor hun rekening.

De belangstelling van het binnenlandse kapitaal ging, zoals eerder opgemerkt, vooral uit naar beleggingen in onroerende goederen, hetgeen tot uiting kwam in de sterk vergrote bouwactivi- 
teit. Voor de lokale houtafzet was belangrijk dat van de nieuwbouw in $195959 \%$ in hout tot stand kwam tegen $31 \%$ in 1957 .

De industriële expansie was tot dusver zeer bescheiden. Dientengevolge nam de werkgelegenheid in veel mindere mate toe dan de beroepsbevolking, waarvan het jaarlijks accres op 2000 werd getaxeerd. De voortgaande automatisering van de mijnbouw en enkele grote industriële ondernemingen onderstreepten het werkloosheidsprobleem nog meer. De veronderstelling ligt voor de hand dat de kosten der werkverschaffing, welke in 1958 inclusief materialen Sf. 0,9 mln en in I96I reeds Sf. 3,4 mln bedroegen, nog zullen toenemen, tenzij een geheel andere koers wordt ingeslagen. Hierbij dient nog te worden opgemerkt dat in I96I ruim 2100 personen bij die werkverschaffing waren betrokken, en dat aan ruim ${ }_{5} 500$ volledig werklozen steun moest worden verleend. Tot $1964 \mathrm{zal}$ het Brokopondoprojekt aan 2000 man emplooi verschaffen, daarna als het werk gereed zal zijn gekomen, slechts aan 600 .

Ten slotte zal naar het oordeel van Amerikaanse adviseurs, in de bevordering van het toerisme een nieuwe bron van welvaart kunnen worden aangeboord. In verband hiermede werd door een particuliere maatschappij een modern hotel gebouwd, deels echter met T.J.P.-gelden. Hoe deze 'industrie' zich zal ontwikkelen valt nog niet te voorzien, maar tot dusver waren de resultaten bescheiden, hetgeen gezien de beperkte attracties, welke Suriname de toerist thans kan bieden, geen verwondering behoeft te baren.

\section{CONCLUSIE}

De tot dusver door het T.J.P. verkregen resultaten gaven nog geen duidelijke aanwijzing, dat men zich op de juiste weg bevond om de doelstellingen te bereiken. In verband hiermede heeft Nederland een verlenging van de planperiode met vijf jaar en een verhoging der fondsen met Sf. $80 \mathrm{mln}$ in overweging genomen.

De vraag rijst of dit tot het gewenste doel zal leiden. De hoogleraren P. Lieftinck en C. Goedhart die in 1960 op verzoek van de Surinaamse Regering ter plaatse een onderzoek instelden naar de economische en financieel-monetaire ontwikkeling van het land, adviseerden tot temporisering van het T.J.P. en tot een zo sober mogelijke inrichting van 's Landshuishouding.

In het Parlement verhieven zich echter onmiddellijk stemmen 
tegen elke maatregel welke zou kunnen leiden tot een verlaging van het consumptiepeil en van het niveau der sociale voorzieningen, beperking der investeringen en verhoging der belastingen. Het advies werd tot op heden dan ook niet opgevolgd.

Of de Regering voldoende kracht zal bezitten om toch het roer radicaal om te gooien zal de toekomst moeten uitwijzen.

's-Gravenhage I.X.r.962

\section{LITERATUUR}

I. E. J. A CAMPO: Landbouwplannen in Suriname. Landbouwkundig Tijdschrift 63, I95I, p. 37 .

2. Samenvattend Eindverslag van het Welvaartsfonds Suriname 1954.

3. R. Kool: Het economisch leven van een stad in een tropisch land. Tijdschrift voor Economische en Sociale Geografie 46, 1956, p. 278.

4. R. A. J. VAN LIER: Samenleving in een grensgebied, r950, Inleiding.

5. W. F. Wertheim: Sociologische aspecten der achtergebleven gebieden. Mens en Maatschappij 35, 1960, p. 349.

6. De markt voor oliën en vetten. Ned. Econ. Instituut Rotterdam, I951.

7. Jон. Gemminк: Voorlopig rapport betreffende de mannelijke agrarische beroepsbevolking in het district Suriname, uitgebracht aan de Stichting Planbureau Suriname. (Ongepubliceerd).

8. A. P. A. VINK: Landclassificatie. Landbouwkundig Tijdschrift 7r, 1959, P. 372.

9. I. A. DE Hulster: Bos en bosbeheer in Suriname 1958. Dienst Landsbosbeheer Suriname.

г. H. J. Матнот: De citrusindustrie in Suriname. Contactgroep Opvoering Productiviteit, 's-Gravenhage, 1952.

II. W. J. M. v.D. WEYDEN : Rapport betreffende de vestigingsmogelijkheden van een keramische industrie in Suriname. Uitgave Stichting Planbureau Suriname, 1952 .

I2. Th. R. Seldenrath: Interne nota Stichting Planbureau Suriname, 1952.

13. Onderzoek naar de mogelijkheden en exploitatie van de ijzerertsreserves in Suriname. Ned. Econ. Inst. Rotterdam, 1951.

14. Joh. J. HANRATH: Voorstellen voor de toekomstige verkeersontwikkeling van Suriname. Uitg. Sti. Planbureau Sur., I952.

15. De grondslagen van een Tienjarenplan voor Suriname. Uitg. Sti. Planbureau Sur. 1952.

16. A. Jonkers: De financiële betrekkingen tussen Nederland en Suriname. Economisch-Statistische Berichten 40, 1955, p. 904.

I7. Verslagen v. d. Centrale Bank van Suriname 1958-1961, in het bijzonder r96o.

18. De algemene financiële en economische ontwikkeling in 196r. Plv. President v. d. Centrale Bank, Paramaribo, 20 sept. 1962.

19. P. LIEFTINCK \& C. GoedhaRT: Rapport inzake de vermoedelijke expansieve invloed op de Surinaamse volkshuishouding en de uitvoering 
van het Brokopondoplan en andere daarmede tegelijk te entameren ontwikkelingsprojecten. 's-Gravenhage, 1959, p. 38-40.

20. Eindrapport. Adviesraad voor de Herziening van het Tienjarenplan. Paramaribo, Dec. I959.

21. Tweede Landbouwtelling. Algemeen Bureau voor de Statistiek, Paramaribo, Nov. 1959.

22. L.V.V. in 1959 en 1960. De Surinaamse Landbouw 8, No. 6, en 9, No. $5 / 6$.

23. H. GongGRIJP: Weekbericht. Vereniging Bedrijfscontact NederlandSuriname, 1955, No. 7-9.

SUMMARY

PREVIOUS HISTORY, PROGRAMME AND RESULTS OF THE

SURINAM TEN-YEAR PLAN

After the Second World War, the Netherlands endeavoured to give Surinam self-government on a sound basis, for which reason this 'Overseas Part of the Realm' had, first and foremost, to be rendered capable of becoming financially independent of the mother country. It was impossible for Surinam to do this on its own-for that, the accumulated arrears of years were too great, and the country's financial resources, derived principally from the production of bauxite, were too limited. Consequently, the Netherlands decided to lend a helping hand.

Fundamental researches into the situation were carried out, the costs of which were defrayed from a 'Welvaartsfonds' (Development Fund) established by the Netherlands in 1947. On the basis of the data thus obtained, a ten-year financing and development plan was drawn up in 1952. The object of this plan was to increase the real income per head of the population; to improve the balance of payments, especially with the Netherlands; and to broaden the country's economic basis, as a result of which opportunities of employment would also be augmented. All this was to be accomplished without lowering the existing level of social services and benefits - in fact, the level was to be raised, if possible; and the financial and monetary equilibrium of Surinam had not to be disturbed.

The plan comprised a number of directly and indirectly productive projects. The indirectly productive projects related to activities in the spheres of traffic and transport (roads, ports, airfields, communications by air and water); social services (schools, hospitals); and scientific research (agriculture, forestry, geology and mining). The directly productive projects lay chiefly in the agrarian sector. Just as in other underdeveloped countries, a very large part of the population of Surinam was dependent on agriculture for a livelihood. Labour productivity in this branch of economic life was low compared with that in industry and mining, and the considerable discrepancy between rural and urban incomes led to increasing urbanization, which brought with it great problems.

Within the framework of the Ten-Year Plan, endeavours were made to raise agricultural productivity per hectare and per man-hour. The latter required an increase in the size of the holdings, which meant that land had 
to be reclaimed. Owing to the nature of the soil, and to communications, this limited favourable prospects to the alluvial coastal plain, where, moreover, the ground was best suited to the cultivation of rice - a not very lucrative crop. And, since this plain lies below sea level, very costly impoldering, drainage and irrigation works were called for.

The cost of the plan was estimated at 127 million Surinam guilders, of which the Netherlands was to provide one third in the form of a grant, and one third as a loan. The rest had to be raised by Surinam - which was considered possible, provided the national economy was organized on a thrifty basis.

Of the above-mentioned total sum, $38.3 \%$ was to be spent on the directly productive projects, and $59.4 \%$ on the indirectly productive projects.

Although the great importance of the interaction between agriculture and industry was fully realized, no large amount of money was reserved for the latter branch of economic life because it was considered that private enterprise should play the biggest part there. If no solution other than that of a 'joint venture' was possible, the Government would then use the planning fund for that. The 'Wageningen' agricultural project, in which rice was being cultivated on large mechanized units with a total area of 6,00o hectares (nearly 15,000 acres), and the gigantic Brokopondo Plan, consisting in construction of a hydroelectric power station and an aluminium foundry, had both, admittedly, been financed from other sources, and therefore fell outside the Ten Year Plan; but they were nevertheless being carried out simultaneously with it. This was bound to lead to great monetary strains if the Government did not show sufficient vigilance.

Since the plan has been functioning unofficially for nearly, and officially for more than a decade, there might by now be indications that its objects are on the way to being achieved.

Unfortunately, it must be stated that, in the last few years, the increase of the gross national product has hardly equalled the growth of the population from which fact a lack in impetus in the economic progress may be deduced. In ten years, the gross production value of the people's agricultural holdings rose by only 10 $\%$, and consequently the lot of the farmer hardly improved at all.

The discrepancy between rural and urban incomes was further aggravated by the constantly advancing mechanization of the chief industrial and mining enterprises. Nor was there any question of broadening the economic basis of the country, since bauxit's contribution to total exports continued to be $82 \%$. Whereas in $195038 \%$ of the income of Surinam was due to the bauxite industry, in later years this figure was even a few per cent higher.

The country's very narrow economic basis became even narrower when, in recent years, exports of some agricultural and industrial products such as rice, coffee, citrus fruits, timber and plywood proved to be highly vulnerable and subject to sharp fluctuations in price. In this connection it is essential to remember that the surrounding countries have the same pattern of production as Surinam, but that their more favourable location with regard to world shipping routes puts them in a better competitive position.

Surinam industry is already heavily handicapped by lack of raw 
materials, relatively high wages, and a very small home market with little financial resources. But it is also confronted by an additional problem which is difficult to solve, in that the surrounding countries often have a very dense agricultural population and try to find a way out of the consequent complications by protecting their industry.

The inadequate home production of consumer goods, combined with the constantly growing amount of money coming into circulation, has caused the quantity of imports and the deficit in the balance of payments to increase. The import of capital is insufficient - Surinam still has little to attract the private entrepreneur; and hence the country's stocks of gold and foreign exchange have declined, thereby causing the cover of the Surinam guilder to fall from $77 \%$ in 1955 to $60 \%$ in 1961 . Owing to rising expenditure, on account of both ordinary and extra-ordinary budget estimates, and the failure of revenue to keep pace with it, the Government has had to call more and more on the home and foreign capital market, as a result of which the Surinam national debt increased enormously within a very few years.

Accordingly, for these reasons there was no question of improving the balance of payments and maintaining financial and monetary stability. The final conclusion must therefore inevitably be that the objectives of the plan have not been approached, and that the economic development of Surinam in the coming years will be a source of great anxiety unless the Government is strong enough to introduce a radical change of policy and take all the measures necessary to ensure thrifty yet efficient management of affairs. 